\title{
A Reappraisal of Iberian Copper Age Goldwork: Craftmanship, Symbolism and Art in a Non-funerary Gold Sheet from Valencina de la Concepción
}

\author{
Mercedes Murillo-Barroso, Manuel Eleazar Costa Caramé, Marta Díaz-Guardamino Uribe, \\ Leonardo García Sanjuán and Coronada Mora Molina
}

Taking as a point of departure the in-depth analysis and description of an exceptional discovery, consisting of a large hammered gold sheet decorated with embossed motifs from the well-known Chalcolithic settlement of Valencina de la Concepción (Seville, Spain), this article presents a general appraisal of the social and ideological role of gold in Copper Age Iberia. The information available for this find, including both its context and its inherent characteristics, opens up new perspectives for research into the technology, use, sociology and symbolism of gold during this time period. We describe and analyse this unique item in detail, including the characterization of the raw material used and the manufacturing process (via SEM-BSE and LA-ICP-MS), as well as an extensive reconstruction of the graphic motifs that are represented, by using digital imaging processing techniques (RTI). We compare this find with the data currently available for the (approximately) 100 Chalcolithic golden artefacts (or fragments of artefacts) found in Iberia to date. Finally, we present an appraisal of the social and ideological framework in which gold was used in Copper Age Iberia, discussing its relevance in aspects such as the dynamics of social complexity, prehistoric worldviews or artistic creations.

\section{Introduction}

The literature on Iberian Neolithic and Copper Age gold metallurgy is fairly limited when compared with that of the Bronze Age and, in particular, the Iron Age. Although published works on Neolithic and Copper Age finds include important contributions (Hernando Gonzalo 1983; Monge Soares et al. 2014; Montero Ruiz \& Rovira Llorens 1991; Nocete Calvo et al. 2014; Perea Caveda 1991; Perea Caveda et al. 2010; Rovira Hortalá et al. 2014; Soriano Llopis et al. 2012), there remain major research gaps, particularly with regard to our 
knowledge of the social and ideological roles of gold. This is the result of a number of factors, mainly that, with few exceptions (Blasco Bosqued \& Ríos Mendoza 2010; Soriano Llopis et al. 2012), there have rarely been publications dealing specifically with Neolithic and Chalcolithic gold artefacts, which, instead, have usually been described briefly in excavation reports or catalogues about early metallurgy. Therefore, it is often the case that the level of detail in the description of the pieces themselves (both in terms of technology and morphology/style) and their contexts has been somewhat limited. In addition, contrary to what occurs with copper-based metallurgy, the analytical body for both the geological characterization of the alluvial resources and, especially, their provenancing, is very limited. These factors have hindered the task of establishing convincing theories concerning the economic, social and ideological/symbolic role that gold, together with other exotic raw materials, had on the dynamics of growing social complexity that are documented throughout the Copper Age (c. 3200-2200 cal BC).

Starting from the study of a recently discovered exceptional piece and its subsequent appraisal within the general context of the known evidence on gold craftsmanship, in this paper we approach the social and ideological/symbolic role of gold in the Iberian Copper Age. This piece, a large hammered gold sheet decorated with embossed motifs, was discovered in 2007 at the PP4-Montelirio sector of the large settlement of Valencina de la Concepción (Seville, Spain) (Fig. 1). In addition to the fact that the item presented here is the largest and heaviest Copper Age Iberian ${ }^{1}$ gold artefact ever recorded (Fig. 2), the interest of this paper stems from the fact that, to date, the gold artefacts discovered at Valencina de la Concepción have not received a monographic treatment within the wider ongoing debate on the relationship between metallurgy and social complexity during this time period (García-Alix et al. 2013; García Sanjuán 2013; García Sanjuán \& Murillo-Barroso 2013; Nocete Calvo 2001; Nocete Calvo et al. 2008; etc.).

Firstly, the PP4-Montelirio artefact is described and analysed in terms of its context, morphology, decoration, manufacture and composition. Then, this piece is appraised within the general framework of gold craftsmanship in Chalcolithic Iberia, exploring its technological, social and ideological aspects. Jointly, the analysis of the new find and its 
comparative assessment with other known gold pieces open up a series of new perspectives for the archaeological study of gold in European early complex societies.
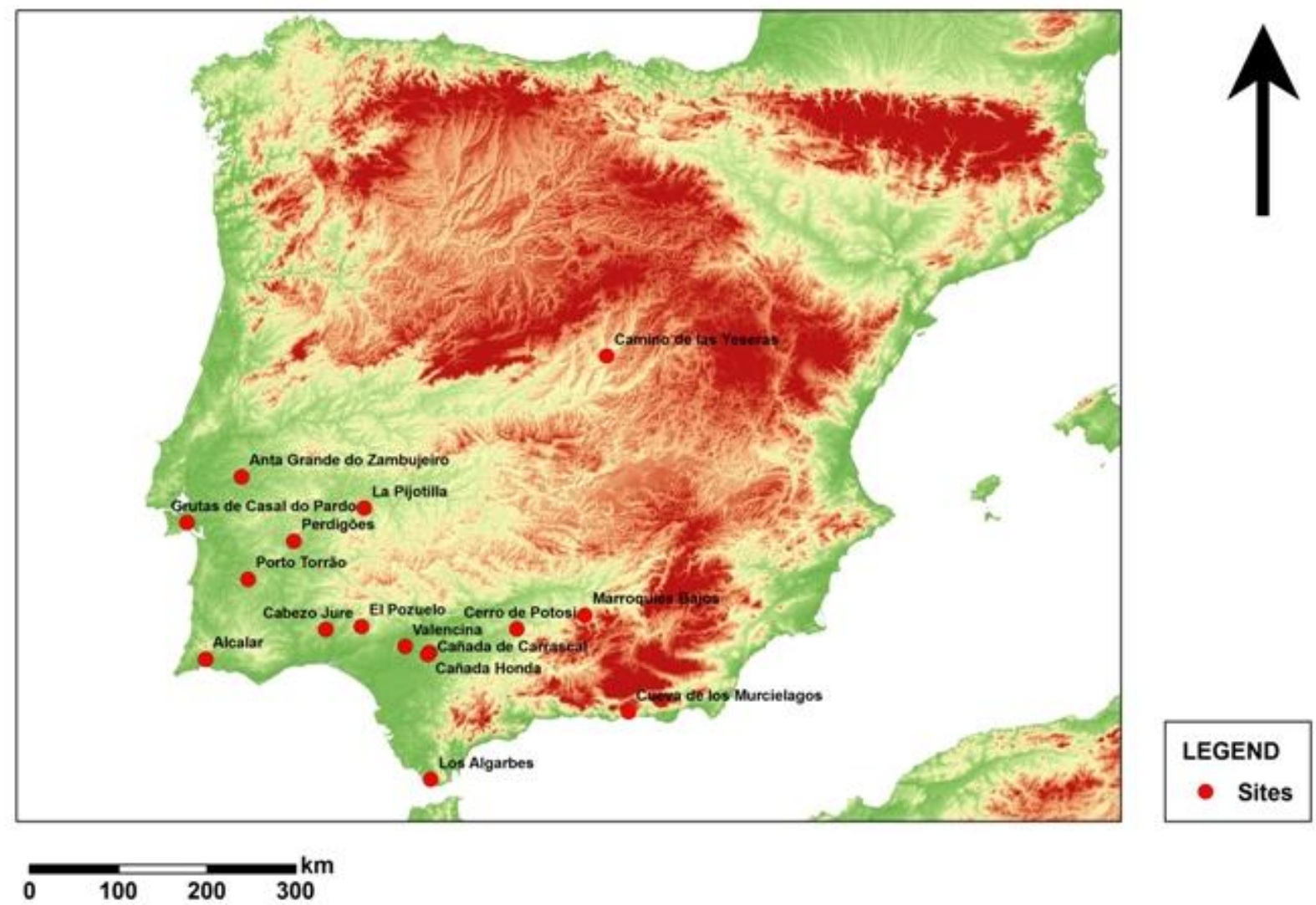

Figure 1. Location of the settlement of Valencina de la Concepcion and the main sites with gold finds mentioned in the text.

\section{The Valencina gold sheet with eye-motifs}

\section{Context}

The settlement of Valencina de la Concepción is widely known in the literature dealing with Iberian Copper Age-cf. a recent synthesis in García Sanjuán (2013). In the last few years, a number of articles published in English have also given international exposure to various aspects of the research on this site (Cáceres Puro et al. 2014; Costa Caramé et al. 2010; García Sanjuán et al. 2013; García Sanjuán \& Murillo-Barroso 2013; Nocete Calvo et al. 2008; RogerioCandelera et al. 2013; etc.). 


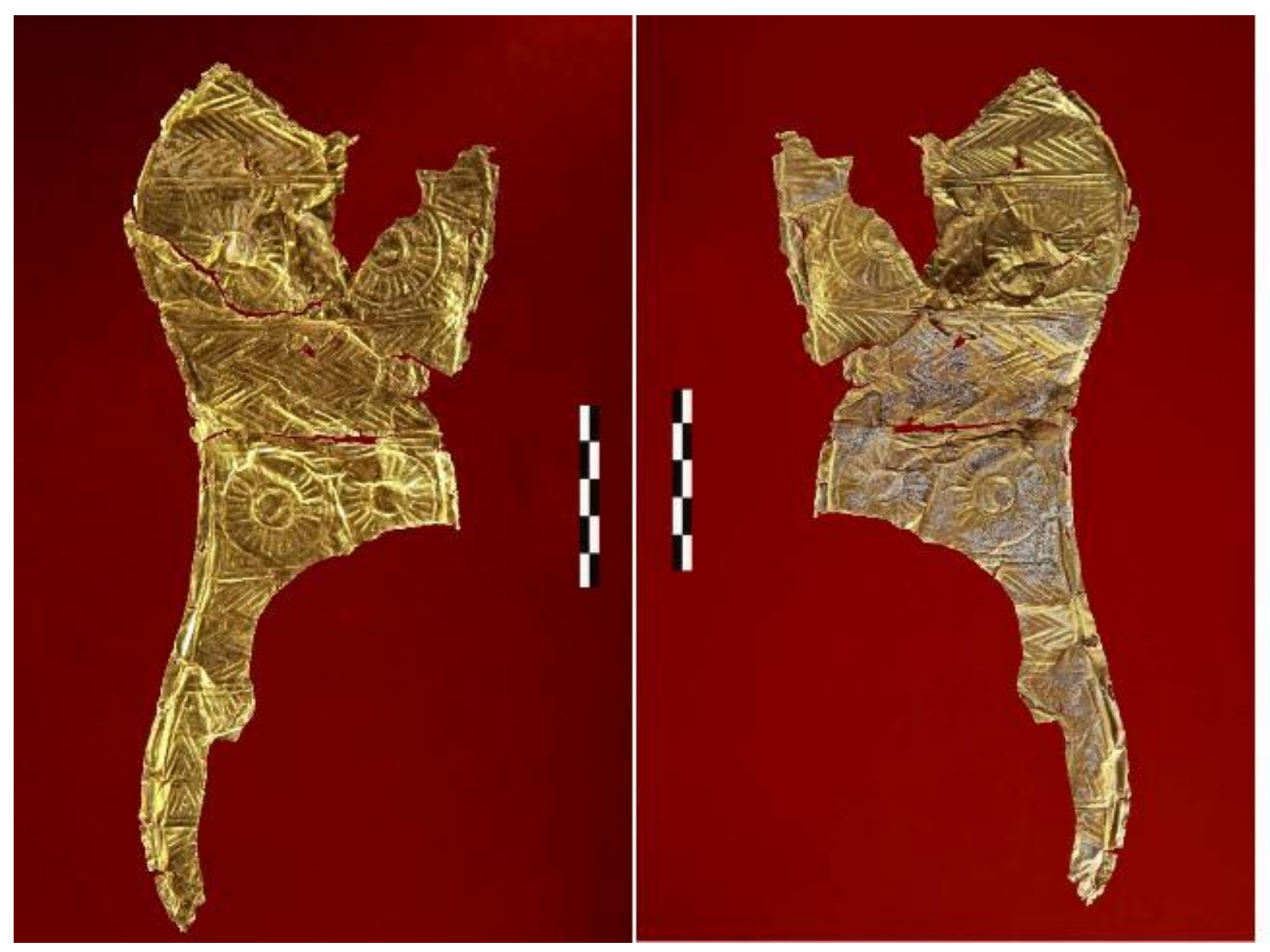

Figure 2. Obverse (left) and reverse (right) of the gold sheet found in the PP4-Montelirio sector of Valencina de la Concepción (Sevilla).

The PP4-Montelirio sector, which is situated in the southwest quadrant of Valencina, in the municipality of Castilleja de Guzmán, was excavated between January 2007 and February 2008. This excavation led to the identification of 134 Copper Age structures, both megalithic and non-megalithic, of which 61 contained human remains and 73 did not (Fig. 3); a summary of the results of this intervention is available in Mora Molina et al. (2013). In January 2011 the Research Group ATLAS (HUM-694) from the University of Seville began a project to study the finds of this excavation that had been stored in the Archaeological Museum of Seville (approximately 100 boxes). By September 2014, work carried out as part of this project included: a full inventory of finds and a preliminary assessment of the overall excavation results (Mora Molina 2011; Mora Molina et al. 2013); a bio-archaeological analysis of the human remains found in structures 10.042-10.049, 10.034 and 10.031 (Robles Carrasco 2011; Robles Carrasco \& Díaz-Zorita Bonilla 2013); the study and restoration of various ivory 
items found in structures 10.042-10.049 (García Sanjuán et al. 2013; Luciañez Triviño et al. 2014); as well as the geochemical characterization of cinnabar pigments (Rogerio-Candelera et al. 2013) and of an exceptional piece of amber (Murillo-Barroso \& García Sanjuán 2013) from structure 10.042--10.049 (the largest megalithic monument of the PP4-Montelirio sector).

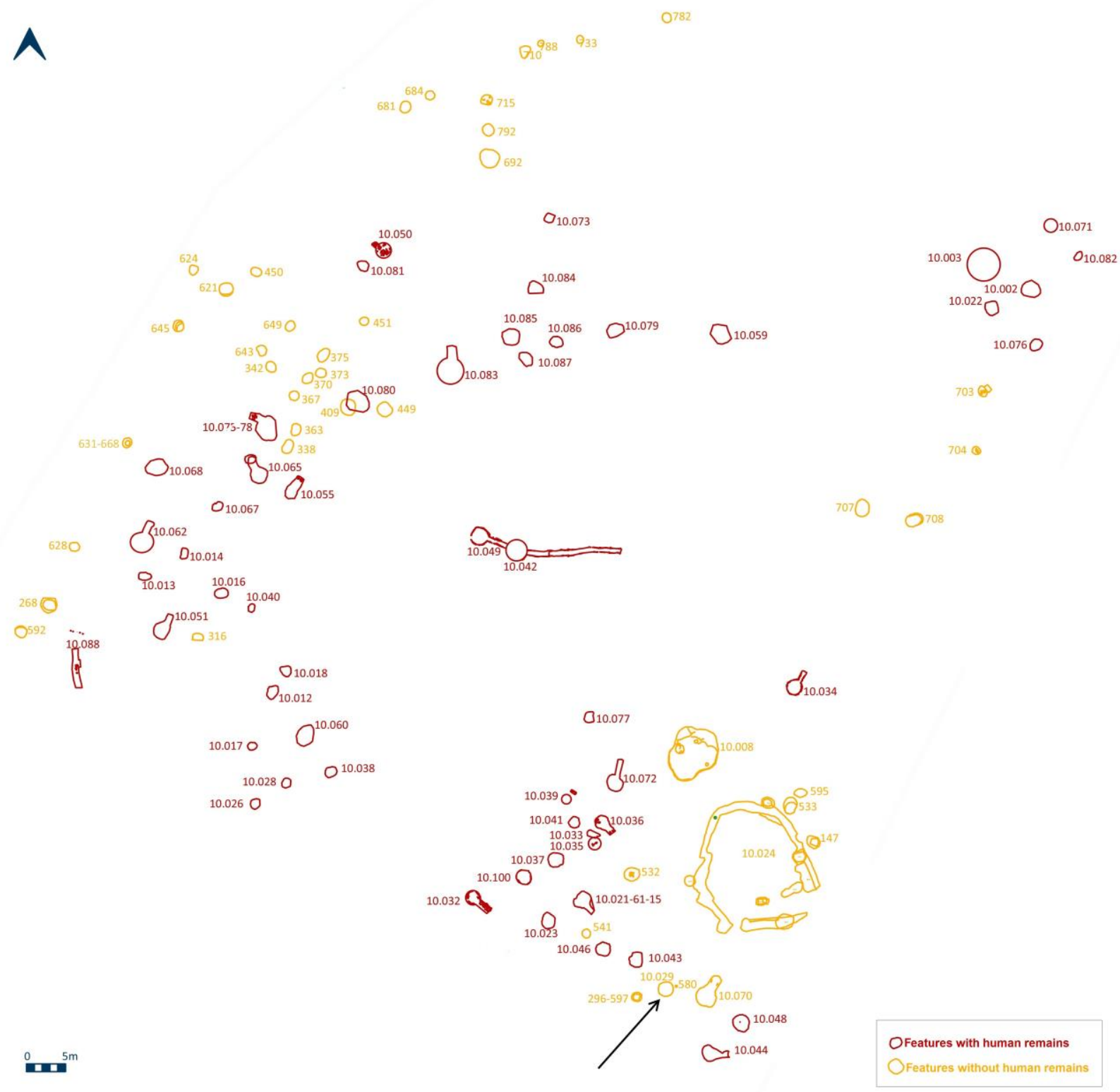

Figure 3. Structures excavated in the PP4-Montelirio sector with and without human remains. The gold sheet was found in structure 10.029, indicated by the arrow.

The gold sheet studied here was recovered in structure 10.029, a pit situated in the southwest area of the PP4-Montelirio sector and in which no human remains were found. Structure 10.029 is approximately $80 \mathrm{~m}$ to the southeast of the large tomb $10.042-10.049$ and 
approximately $12 \mathrm{~m}$ to the south of structure 10.024, a large round area, approximately 20 $\mathrm{m}$ in diameter, surrounded by a ditch and in which no human remains were discovered either (Fig. 3). It must be borne in mind that in the PP4-Montelirio sector, as in the whole Valencina de la Concepción site, structures with and without human remains appear spatially mixed in what seems to be a random manner - to date, no spatial patterning has been detected for either of them (Costa Caramé et al. 2010; García Sanjuán 2013). This issue is particularly relevant in relation to the functional, social and ideological interpretation of the piece studied here, which we will discuss later on.

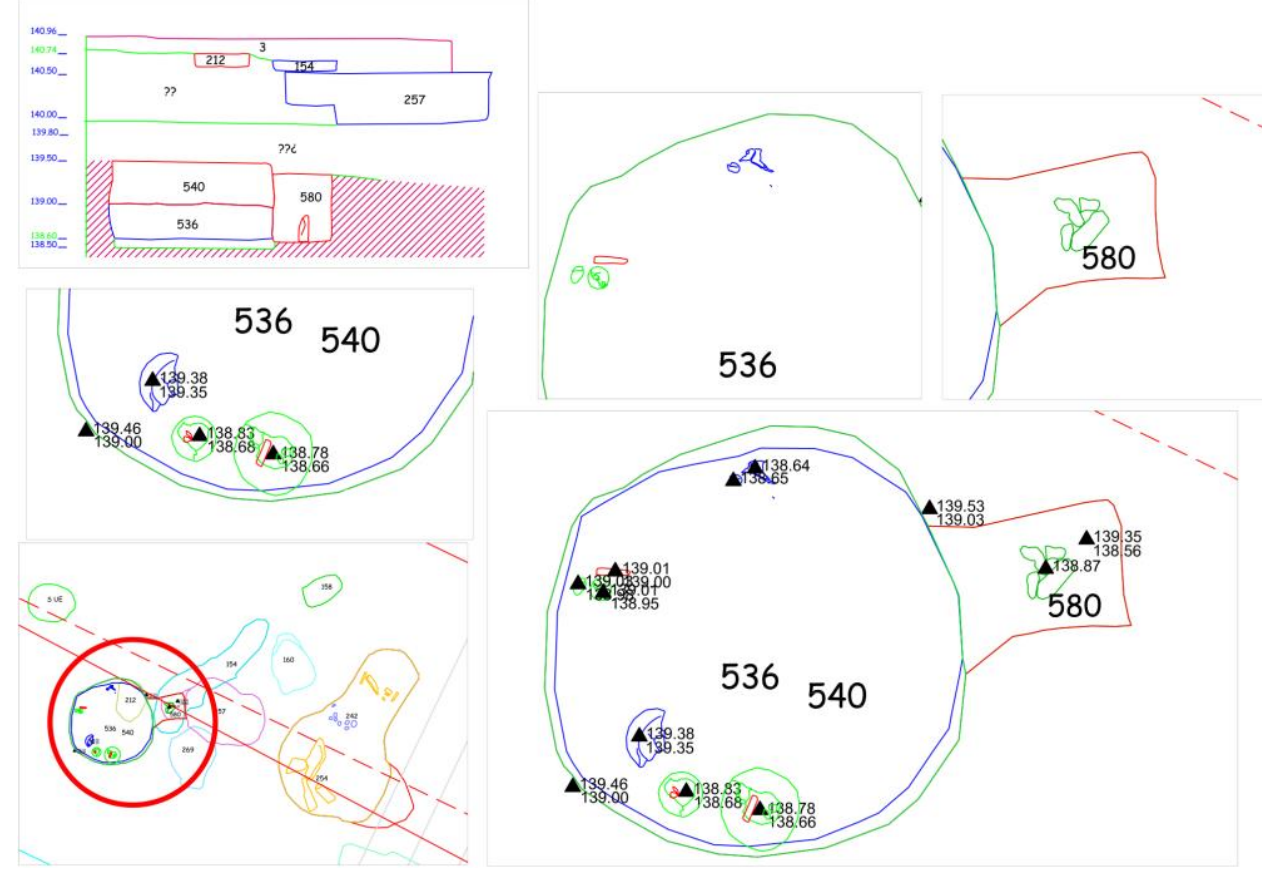

Figure 4. Plan and section of structure 10.029 where the gold sheet was found.

From an architectural point of view, structure 10.029 is a circular pit with a maximum diameter of $1.95 \mathrm{~m}$ and an approximately spherical section, with between 1 and $1.10 \mathrm{~m}$ maximum depth (Fig. 4). On its eastern edge, a small lowered area, $0.77 \mathrm{~m}$ in length by 0.59 $\mathrm{m}$ wide, was found with four small slate stones laid horizontally and grouped together. The PP4-Montelirio excavator described this small feature as a 'corridor' to a possible 'small megalithic structure'. Although the excavator's observation may be understandable in view of the position of this lowered area to the east of the circular structure and because of the presence of some small slates (a material normally associated with tombs in Valencina), this 
architectural interpretation can be totally ruled out for a number of reasons: first, because of the minute size of the slate stones (the largest of the four was barely $20 \mathrm{~cm}$ long) which make it impossible to describe them as the 'slabs' of a 'megalithic' structure; secondly, because of the tiny size of the 'corridor' and the alleged 'chamber' (the circular pit), where one person would barely fit; and thirdly, because of the large difference in depth between the first and the second $(1 \mathrm{~m})$, which is unheard of in Iberian megalithic structures.

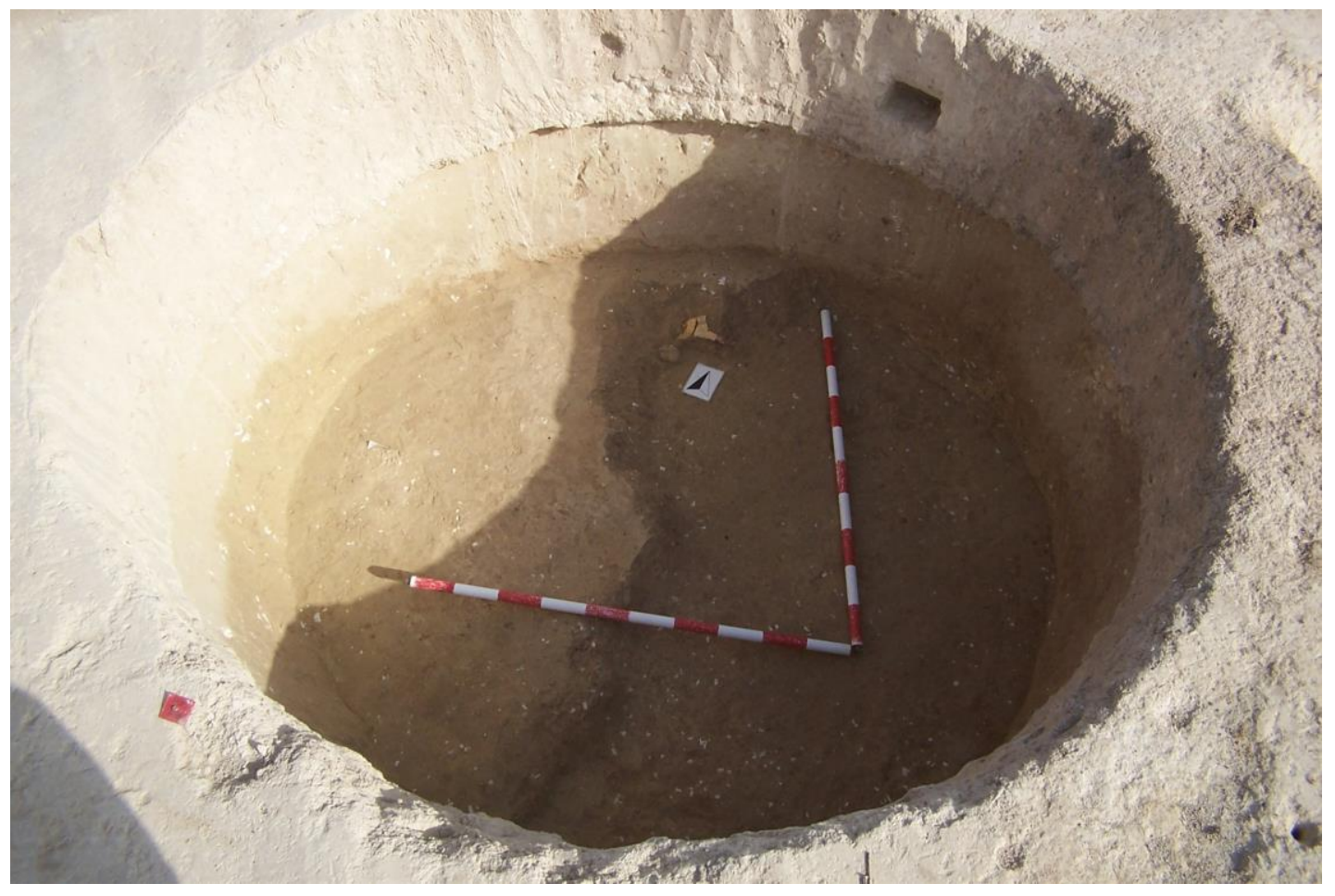

Figure 5. The gold sheet in its archaeological context.

With regard to the infill of structure 10.029 , the description provided by the excavator distinguishes four levels or deposits of materials at different depths. These could represent a sequence of use, the chronology of which is unknown, given that no radiocarbon dates are available (no organic materials are reported for this pit). From bottom to top, the description is as follows. On the lowest depositional level, the gold sheet (Fig. 5) was discovered at a depth of between 100 and $110 \mathrm{~cm}$ (UE 536, a dark brown clay-like infill), on the northern half of the pit and with no immediate association with other artefacts. The second depositional level, approximately $80 \mathrm{~cm}$ in depth (still in UE 563), included two ceramic globular vessels, each of them containing a flint blade (Fig. 6). In the third depositional level, also part of UE 536, and at a depth of approximately $60 \mathrm{~cm}$, were two ceramic vessels and 
one flint blade. Above these levels was the structure's fourth depositional level (UE 540), approximately $40-50 \mathrm{~cm}$ thick, which is the structure's upper infill and within which only a fragmented ceramic plate was discovered. No human remains were found in any of these levels. Above this was the topsoil, which included wheel-thrown pottery.

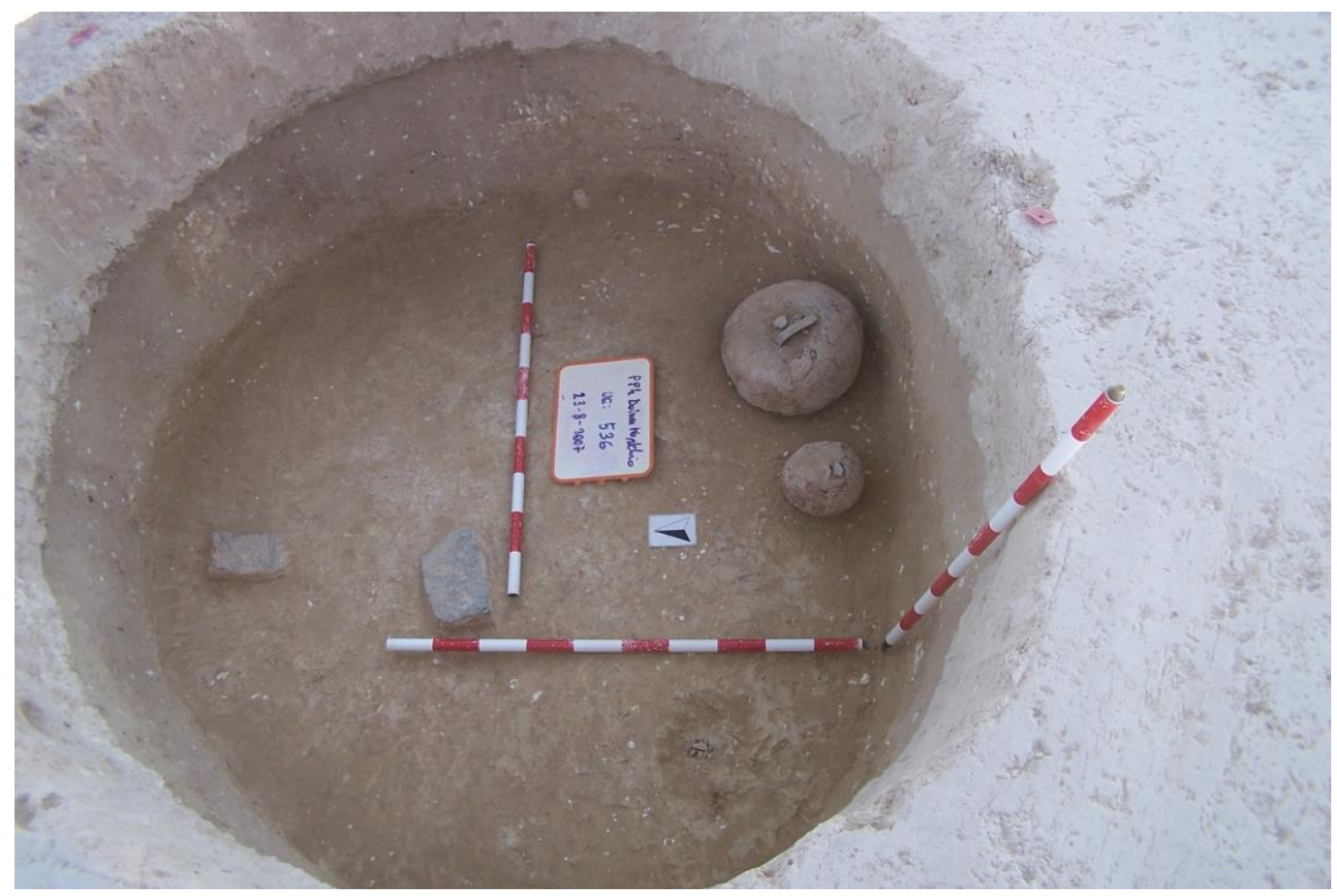

Figure 6. Upper deposit in which two pottery globular bowls and flint were found.

\section{Morphology and decoration}

The sheet, that basically resembles the shape of a skein or the figure 8 , is $20.5 \mathrm{~cm}$ long, 9.8 $\mathrm{cm}$ wide, $0.004 \mathrm{~cm}$ thick and weighs 10 grams. In accordance with the orientation we have given it (Fig. 7), from top to bottom the piece has two important areas that have been destroyed: one relatively small at the top right-hand corner and another, much larger, which practically affects its entire lower third. Taking this damage into account, we estimate that its original weight might have been around $20 \mathrm{~g}$. An interesting aspect of this piece is the noticeable asymmetry of its design, as the upper part is shorter that the lower part. To be exact, if the horizontal moulding that separates strips 3 and 4 are taken as a reference, the upper part is approximately $11 \mathrm{~cm}$ while the lower part is $14 \mathrm{~cm}$ high. 
Another aspect that is worth mentioning about the morphology of this object, particularly with regard to its functionality, are the series of perforations on its left and right edges (Fig. 8). Although the edge of the sheet is damaged on both sides, the left side clearly shows 8 perforations distributed at rather regular intervals measuring between 1.5 and 2 $\mathrm{cm}$ in length. Furthermore, although we cannot state for certain that the rest of the left side had more perforations, there are a number of damaged areas that suggest that these may have been perforations. The right-hand side of the piece shows only one perforation clearly, although once again the toothed shape of the edge suggests that there were originally more: these are no longer clearly visible. These perforations indicate that, at least at some point in its biography, the gold sheet was attached (with a vegetable or animal fibre) to a support which has not been preserved and which could have been made of wood, leather, cloth or even ivory (see discussion below).

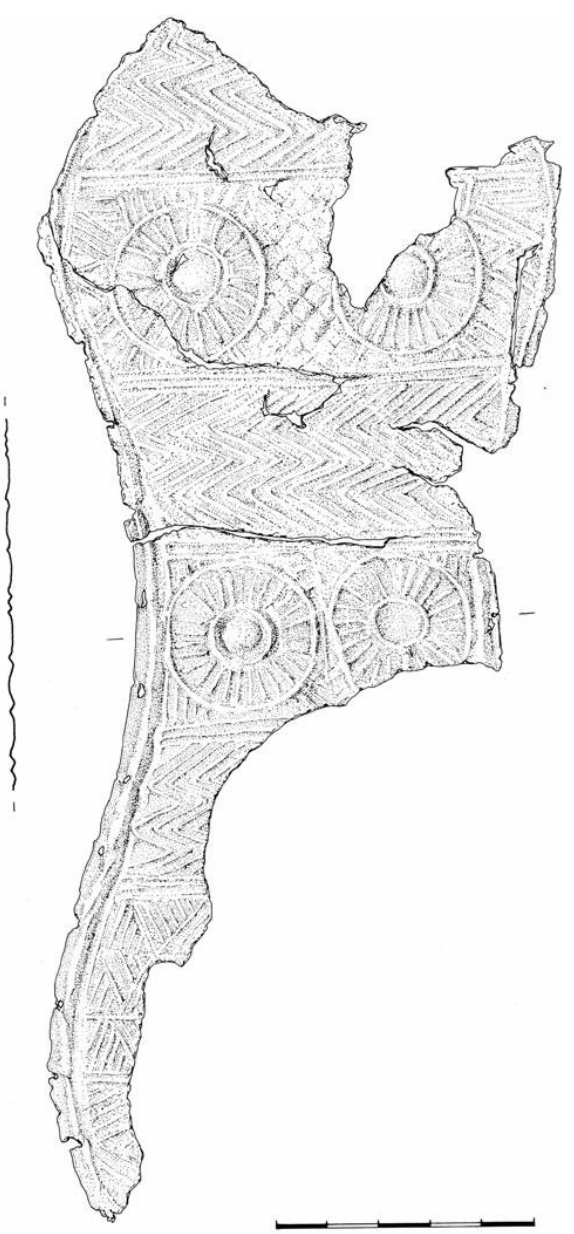

Figure 7. Drawing of the gold sheet.

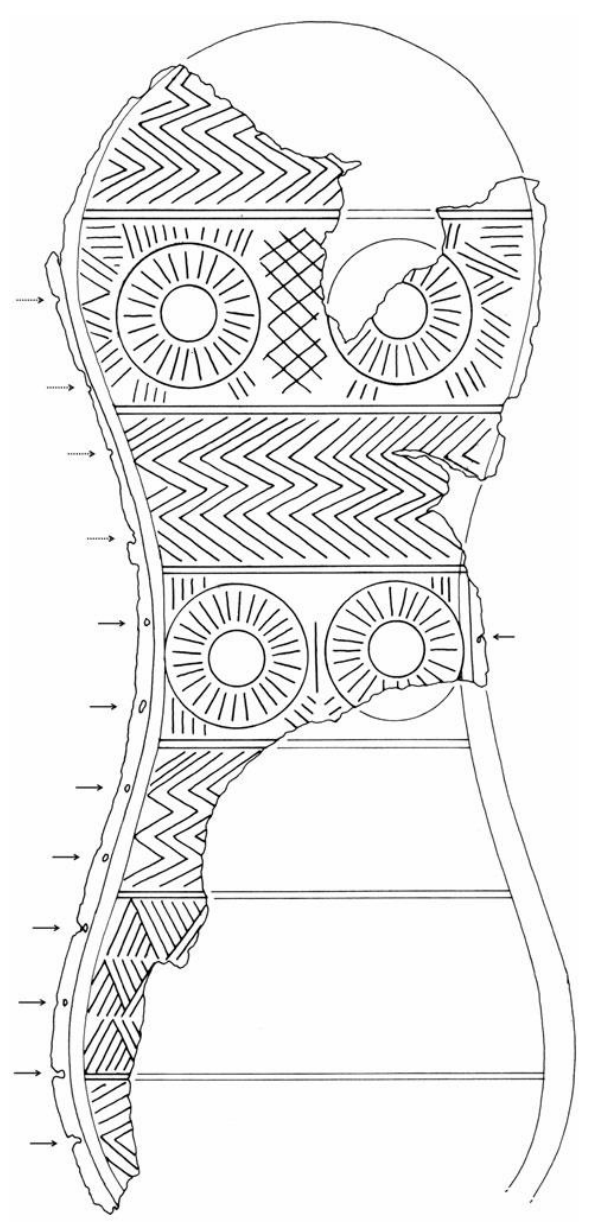

Figure 8. Schematic drawing of the gold sheet with the decorative strips delimited. Arrows show the perforations identified. 
With regard to decoration, the piece appears generously decorated with embossed geometric motifs. Seven individually decorated vertical strips can be distinguished, separated in all cases by two linear mouldings that go across the piece transversally (Fig. 8). For greater clarity in the description, these strips have been numbered 1 to 7 in descending order. Strips 1, 3, 5 and (maybe) 7 have vertical zigzag lines. Strips 2 and 4 have eye motifs made up of a circle surrounded by short straight lines that radiate from it, and which are themselves enclosed in another exterior circle. Finally, strip 6 has, as far as can be seen, since the piece is very damaged in this area, what appears to be a series of chevrons or motifs vaguely similar to spikes. What is particularly interesting in strip 2 , between the two eye motifs, is a dotted motif that does not appear in the rest of the piece (Fig. 9). This decoration was done with a quadrangular section punch, which gives a slight pyramidal appearance similar to the decoration of the Matarrubilla fragments of gold sheet, and which is also identical to the one identified in some of the engraved ivory pieces found at the PP4Montelirio sector of Valencina de la Concepción. ${ }^{3}$

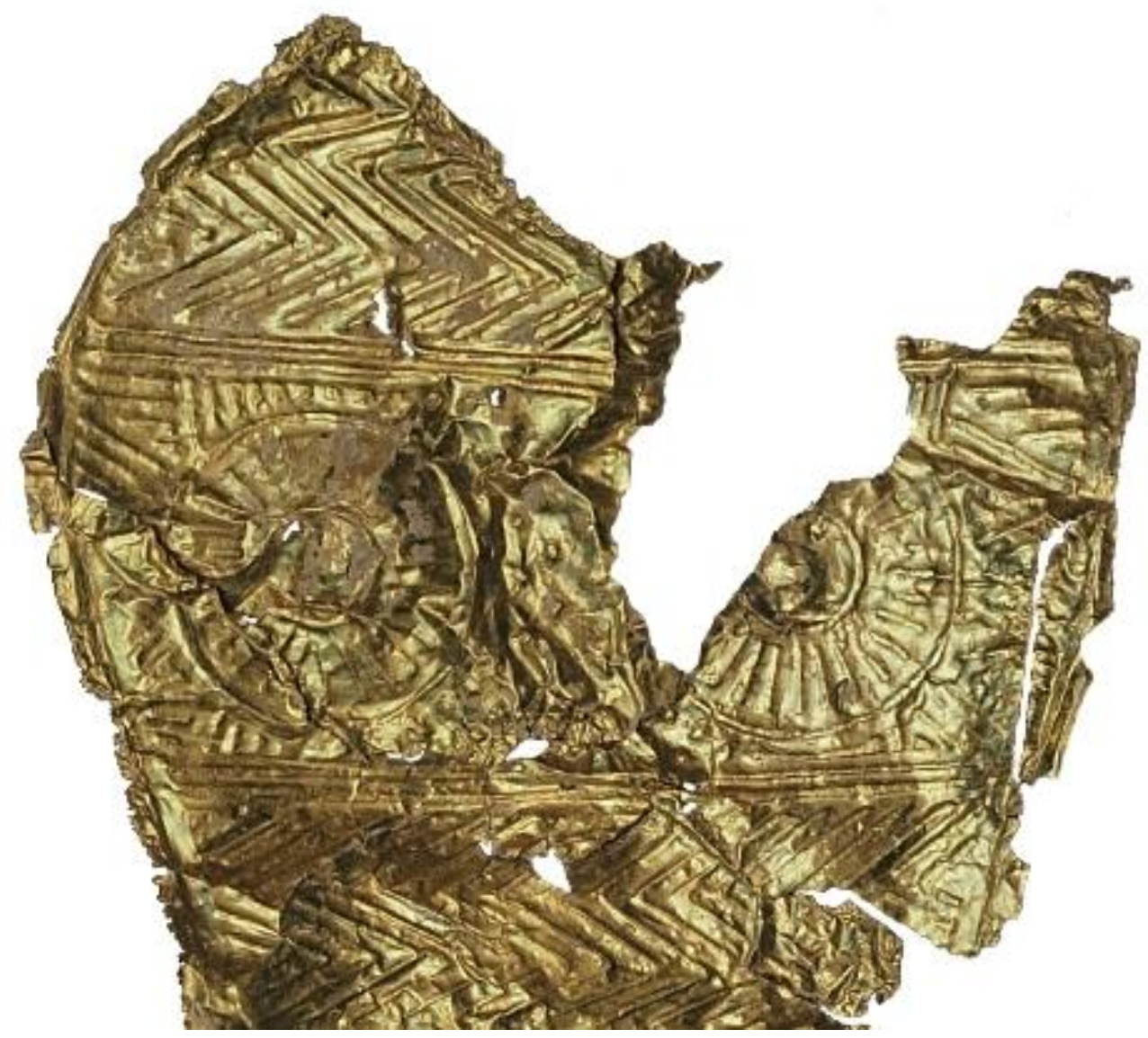

Figure 9. Detail of the decoration of the three upper strips, including two eye motifs in strip 2. RTI image capture with unsharp mask enhancement (RTI Viewer 1.1.0, http://culturalheritageimaging.org/Technologies/RTI/). 


\section{Manufacture and composition}

Copper Age gold objects were mainly made in the form of fine sheets of gold that were hammered until a thickness of c. 0.005-0.01 cm was obtained (Perea Caveda 1991, 24). Gold is the most malleable of all known metals (Van der Lingen et al., 2004, 2050) and thin foils or sheets which can be easily rolled or moulded are therefore relatively easy to obtain by pounding. However, creating thin sheets of gold required experience in the art of beating (carried out indirectly, placing skins or other soft materials over the gold to avoid damaging it). In the case of the PP4-Montelirio piece, the embossed decoration also clearly involved great skill.

The metal from this piece may have been obtained in two ways:

- With a small nugget that did not require any further preparation before the hammering process. Gold nuggets can be easily found in rivers and separated by its high density $\left(19.32 \mathrm{~g} / \mathrm{m}^{3}\right)$ (Delibes de Castro 1977, 113), which perhaps explains the generally small size of Copper Age gold objects, usually weighing no more than $5 \mathrm{~g}$. The sheet from structure 10.029 is extraordinary in this sense, as a rather large gold nugget must have been discovered and then processed to make it (the entire piece may have weighed around $20 \mathrm{~g})$. Gold is a very dense metal and one pure gold nugget measuring little more than 1 cc can weigh $20 \mathrm{~g}$.

- A second possibility is that a number of gold nuggets were melted down, which would have been technologically feasible, since in Copper Age Valencina, copper was already being melted-and the melting point of copper $\left(1085^{\circ} \mathrm{C}\right)$ is slightly higher than that of gold $\left(1064^{\circ} \mathrm{C}\right)$. This second option would involve melting various nuggets in a crucible and then working on the regulus that would remain in the crucible, or the prior preparation of a small ingot. This way the gold composition would be homogenized and would be freed from any sand impurities that may have become encrusted in the irregular shapes of the nuggets and which could hinder the hammering process and the process of obtaining thin sheets (Perea Caveda et al. 2010, 248). The discovery of a gold regulus at the Alamillo Street sector (López Aldana et al. 2001; Nocete Calvo et al. 2014, 695) confirms that this technology was used in Chalcolithic Valencina. 
We are, therefore, inclined to believe that the technological process used was the latter, particularly suitable for creating large thin sheets.

Once melted, the gold would have been hammered indirectly by placing a soft surface (thin fabric or skin) between the metal and the hammer, so as not to damage the metal and leave obvious marks, and a $0.004 \mathrm{~cm}$ thick sheet would be obtained, which was then cut to its final shape and decorated. In order to obtain a sheet with this thickness, the hammering stages were probably alternated with annealing stages (gold re-crystallizes at $\left.650^{\circ} \mathrm{C}\right)$. The heat makes it more malleable and ductile, which was diminished during the hammering stage, so annealing enabled new hammering stages without causing it to break-the recently published metallographies of other Copper Age gold sheets show a warmed-up forged microstructure (Monge Soares et al. 2014, 122; Nocete Calvo et al. 2014, 700). Once the required thickness was obtained, the sheet could be cut quite easily using a sharp piece of flint, given its reduced hardness and thickness.

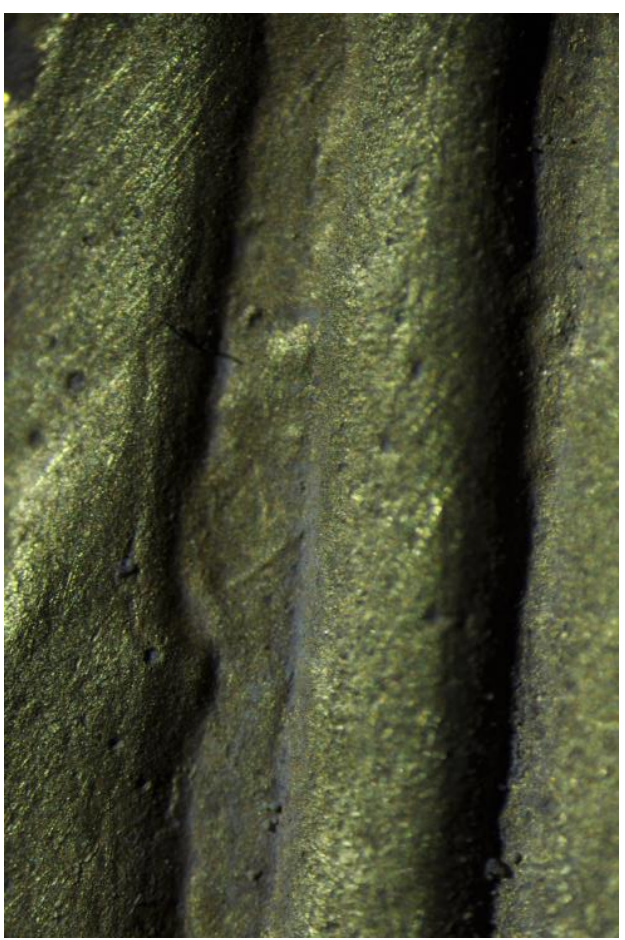

Figure 10. Detail of the reverse of the gold sheet where the quadrangular section of the burin can be appreciated. This matt appearance of the reverse in contrast to the obverse suggested that the reverse was not polished (confirmed by SEM analysis); therefore diagonal lines on the upper part of the image should be related with subsequent post-depositional, excavation or conservation processes.

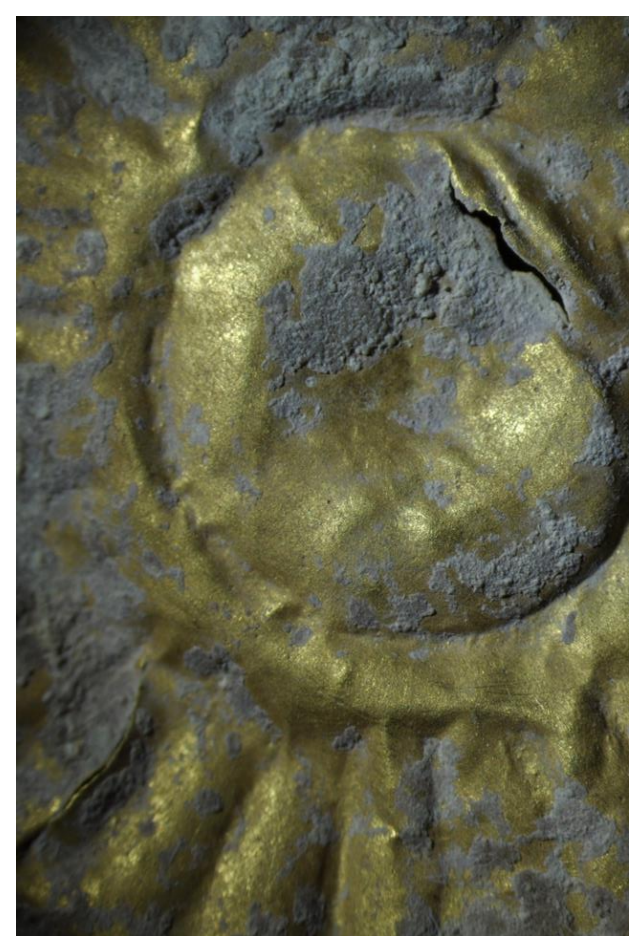

Figure 11. Detail of the eye motif on the reverse. Note that the circular trace was interrupted several times. 
The embossed decoration of the piece from structure 10.029 was produced by using a burin of quadrangular section (Fig. 10). The use of some sort of stamping device can be ruled out, since the back of the sheet (where the embossed work was done) clearly shows the goldsmith's intermittent lines. For example, Figure 11 shows that the eye-motif circumferences were not made with a single stroke, the goldsmith clearly interrupting the line layout a few times. Inside some of the radial lines of the eye motifs are a series of imprints that may have been from the material supporting the sheet, although they may also be imprints caused by post-depositional processes (Fig. 12).

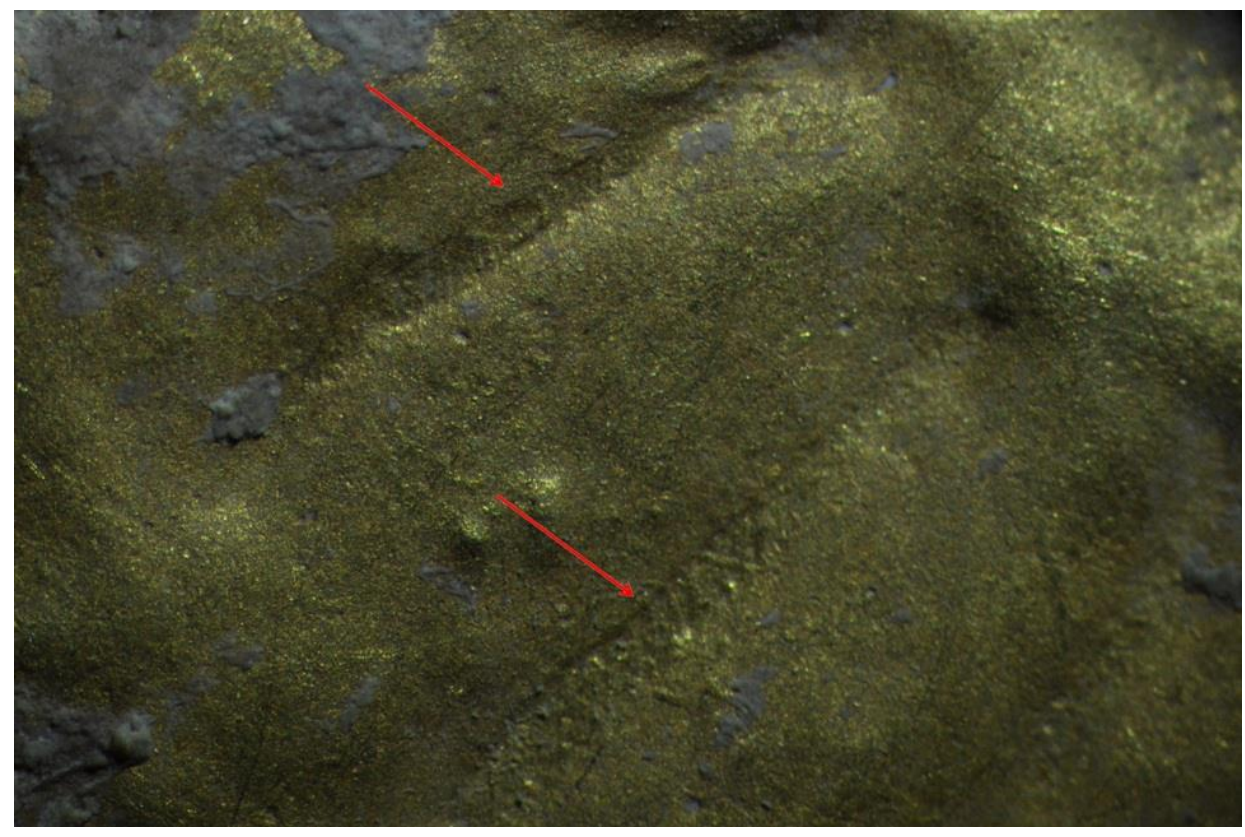

Figure 12. Detail of the imprint observed in two perpendicular lines of the eye motif.

The front side of the piece was then polished to provide it with a shiny gold appearance, while the back was left unpolished and with a matte gold finish. Finally, the perforations on the edges were done from the front side, as the borders of the remaining metal can be seen protruding towards the back (Fig. 13a). Some of the perforations are torn parallel to the border of the sheet perhaps as a result of the tension produced by the fibre used to sew the piece to its support (Fig. 13b). If this is the case, this is probably a piece that was 'sewn' rather than 'stapled'. 

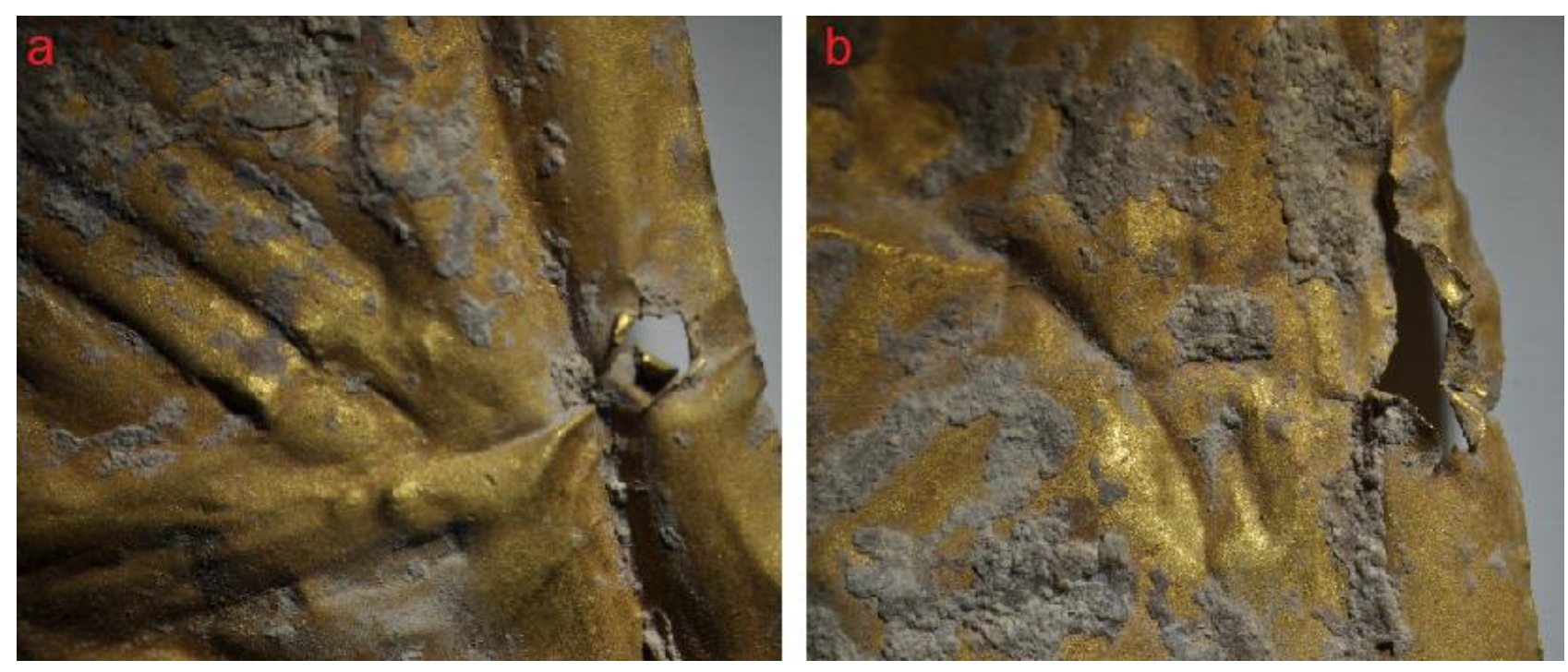

Figure 13. Detail of the perforations in the reverse of the sheet showing that they were performed from the obverse. Note in $13 \mathrm{~b}$ that some of these perforations are torn as a consequence of the tension applied by the fibre which sewed the sheet to its support.

Observation with the Scanning Electron Microscope (SEM) $)^{4}$ confirmed the presence of scrubbing abrasion marks on the surface, with superimposed scratches and damage that occurred after the piece had been made (Fig. 14a). The reverse has a rough and irregular texture (Fig. 14b) which confirms that only the front side was polished and suggests that the back was probably not made to be looked at (which lends further support to the idea that the piece was sewn to a base or support).
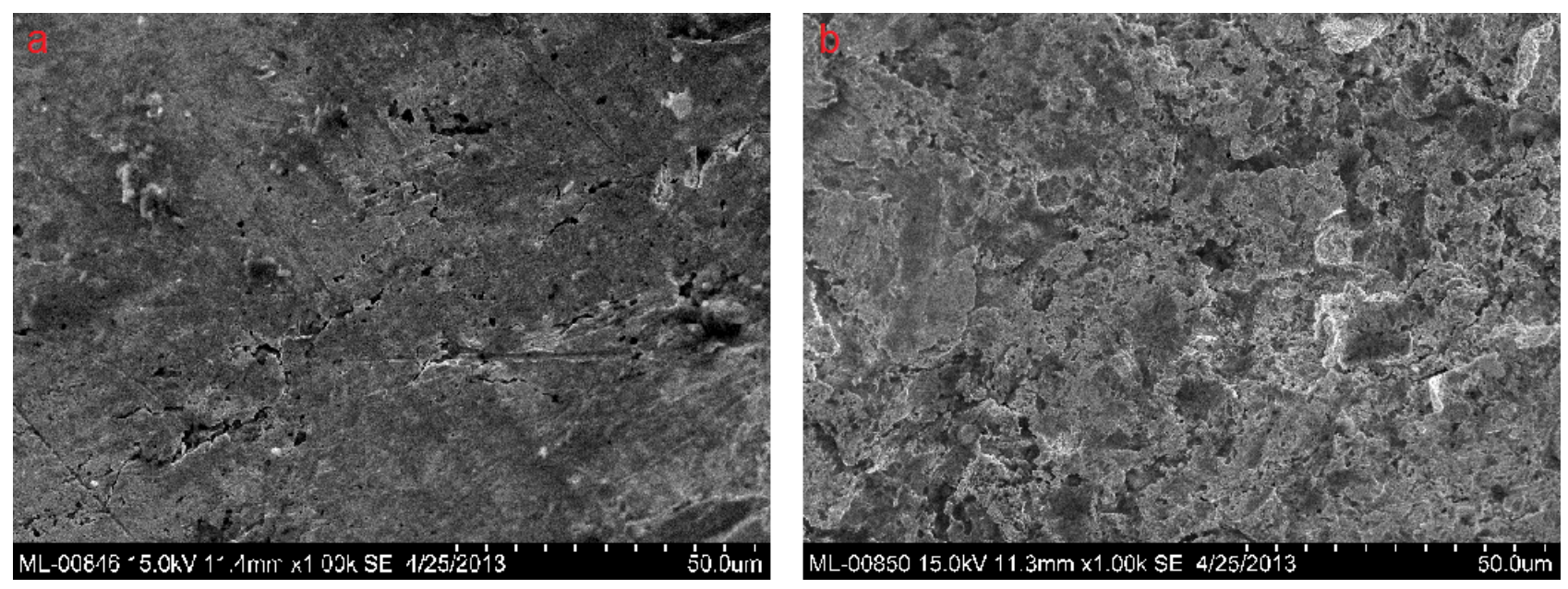

Figure 14. SEM-BSE micrographs of the obverse (a) and the reverse (b) of the gold sheet. Polishing lines can be observed on the obverse surface, showing a smooth appearance. The coarse appearance of the reverse indicates that it was not polished. 
The elemental composition ${ }^{5}$ of the PP4-Montelirio foil shows an extremely pure gold (99 per cent), with small silver and copper impurities (Table 1). The low levels of silver $(<1$ per cent) are particularly interesting, since Iberian gold objects normally have concentrations of silver above 3-4 per cent (even reaching 14 per cent Ag in a sheet from Valencina de la Concepción-Table 1: item listed as MIDAS 487), with the exception of the objects from Perdigões (Monge Soares et al. 2014) and those analysed by Scanning Electron Microscope-Energy Dispersive X-Ray Spectrometer (SEM-EDS), which show slightly lower levels, perhaps because of the reduced accuracy of the technique with objects without sample preparation (the levels of silver in the sheets from Matarrubilla analysed by OES, for example, showed greater concentrations of silver than those obtained when analysed by SEM-EDS; see Table 1).

\section{Discussion}

\section{Gold artefacts in the Southern Iberian Copper Age}

Because of the good-quality information concerning the context in which it was found, its large size, its decoration, its composition and its general excellent condition (despite almost half of it being missing), the PP4-Montelirio gold foil looks all the most exceptional when compared with the $c .100$ Neolithic and Copper Age gold artefacts (many of them small fragments) so far documented in Iberia (Table 2).

The oldest piece of this series is possibly the diadem found in Los Murciélagos cave (Albuñol, Granada, Spain) in 1857 which surrounded a skull described as masculine (Góngora y Martínez 1868: 28-9) (Fig. 15a). The four radiocarbon dates obtained from samples of the esparto-grass baskets found in this cave (and kept in the National Archaeological Museum, Madrid) dated it to the first half of the fifth millennium cal BC (Cacho Quesada et al. 1996). To date, this appears to be the oldest time horizon for the use of gold in the Iberian Peninsula. In the Copper Age, gold artefacts became comparatively more frequent - although always within rather reduced quantitative parameters in absolute terms. The majority of the Copper Age gold finds come from a reduced number of sites, including Las Canteras, Marroquíes Bajos, Camino de las Yeseras, Los Algarbes, Alcalar, 
Anta Grande do Zambujeiro, San Pedro de Estoril and Valencina de la Concepción, all located in southern, western and central Iberia.

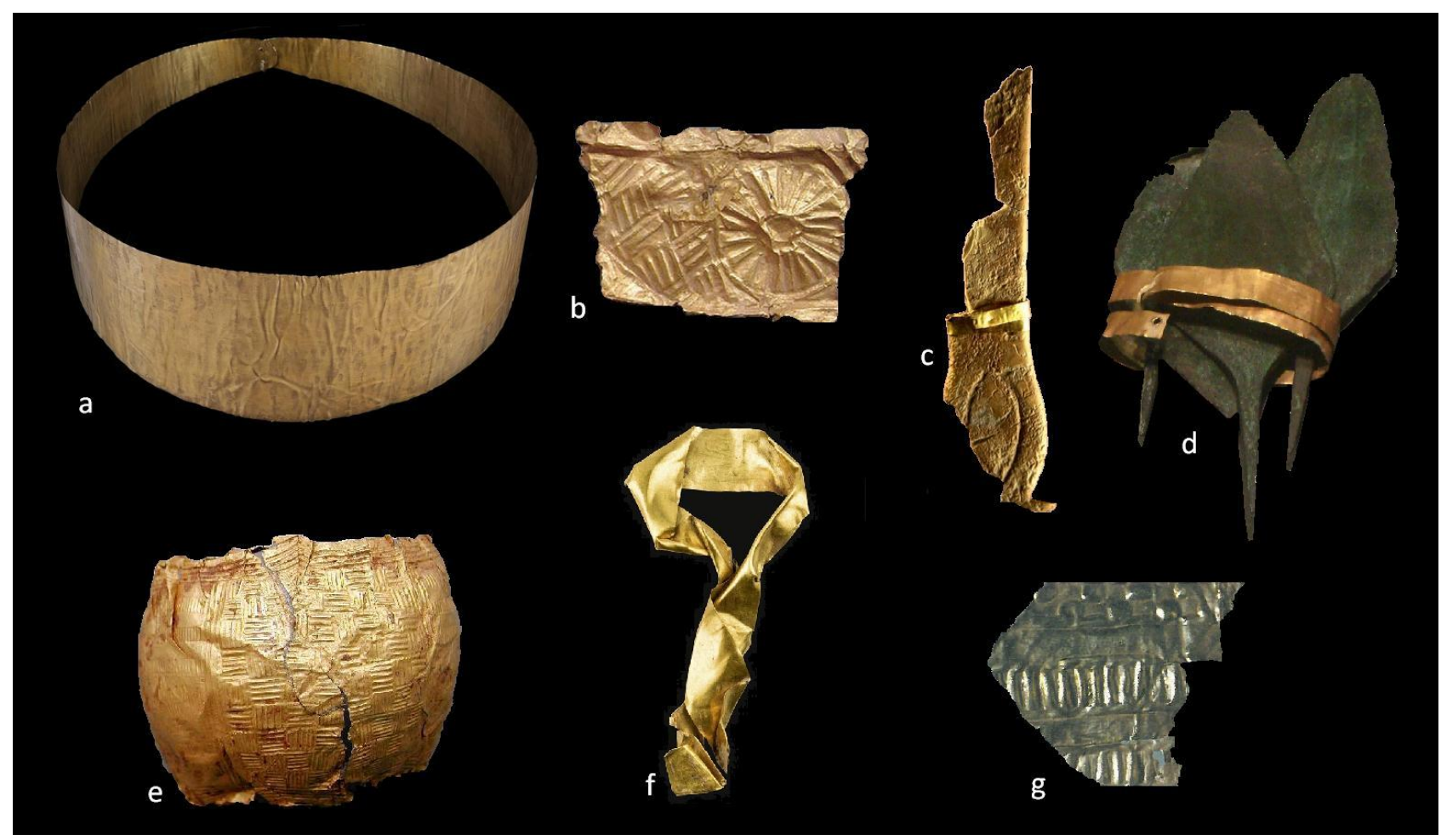

Figure 15. Some gold finds mentioned in the text. a) Diadem from Cueva de Los Murciélagos (Albuñol, Granada); b) Decorated sheet from the tholos of Las Canteras (Alcalá de Guadaira, Sevilla); c) Gold sheet holding a bone idol from Marroquies Bajos (Jaén); d) Golden sheet holding Palmela points, Villaverde del Río (Sevilla); e) Decorated sheet from Los Algarbes (Tarifa, Cádiz); f) Gold sheet from Calle Trabajadores (Valencina de la Concepción, Sevilla); g) Decorated sheet from the tholos of Matarrubilla (Valencina de la Concepción, Sevilla). Figures are not to the same scale.

In the Las Canteras tholos (Alcalá de Guadaira, Seville Spain), which is part of the great prehistoric and protohistoric site of El Gandul, a small fragment of a gold sheet also decorated with embossed eye-like and linear motifs was discovered (Hurtado Pérez \& Amores Carredano 1984) (Fig. 15b). This artefact was found in the corridor of the tholos, specifically in the entrance to the chamber, together with fragments of vessels, bowls, globular containers and ceramic plates, arrowheads and flakes of flint, polished axes and necklace beads. Around the edges of this sheet there are creases that could have been used to fix it to a base made of wood or leather (Hurtado Pérez 2009, 151).

In Marroquíes Bajos (Jaén, Spain) two gold artefacts were found: the first is a sheet decorated with zigzag motifs; the second is a narrow foil with two holes for rivets that was 
found surrounding the waist of an anthropomorphic figurine made of bone (Costa Caramé 2009, 192) (Fig. 15c). At Villaverde del Río (Seville, Spain) a thin sheet of gold was found surrounding a set of copper arrowheads-the context of this find is unknown (Serna González 1989, 79) (Fig. 15d).

At the site of Camino de las Yeseras (San Fernando de Henares, Madrid, Spain) 26 pieces of gold were discovered, including 22 beads, 3 sheets and one belt (Blasco \& Ríos 2010). One of the beads and the laminar belt form part of a grave that was pillaged, while a semi-circular sheet is also from a very damaged context of unknown function (although the excavators do not rule out the possibility of it being a looted grave) and the rest of the pieces (21 beads and 2 sheets) are from the same grave and would have formed part of a personal ornament, since they were discovered around the skull of an individual whose grave goods also included an ivory necklace and cinnabar pigments. According to the interpretation of the excavators, the beads would have been sewn to a strip of fabric or leather. A similar sheet was also found on the temple of an individual in a grave of Humanejos (San Fernando de Henares, Madrid).

Two decorated gold sheets were discovered in the megalithic necropolis of Alcalar (Portimão, Faro, Portugal). The first, from tholos number 11, has triangular and linear motifs and appeared associated with flint blades, flint arrowheads, a polished stone chisel and three ceramic urns (Morán Hernández et al. 2007). The second sheet, decorated with a grid, appeared in grave number 4 in association with flint blades and arrowheads, necklace beads and fragments of a plate (Morán Hernández et al. 2007). Two fragments of sheets decorated with an embossed spike that may have been part of the same piece, given their similarity, appeared in the dolmen of Anta Grande do Zambujeiro (Évora, Portugal). One of the two sheets had a number of lateral orifices. The information concerning its context and associated artefacts is fairly scarce and imprecise (Hurtado Pérez 2009, 151).

A dozen gold sheets and two rectangular strips were also recovered in the chamber of Tomb 2 in Perdigões (Évora, Portugal). It is suggested that these 12 gold foils were also attached to some sort of fabric backing, as they had a shiny obverse and a dull reverse, and a mixture of clay and beeswax has been identified on the back of the foils, probably used in their attachment to a fabric backing (Monge Soares et al. 2014, 123). The gold strips (c. $13 \mathrm{~cm}$ 
long and $9 \mathrm{~mm}$ wide) presented two perforations, although due to their thickness they could have been used as a diadem without the need of any supporting material (Monge Soares et al. 2014). Four samples of human bone have been dated from this tomb: Beta-308789, from

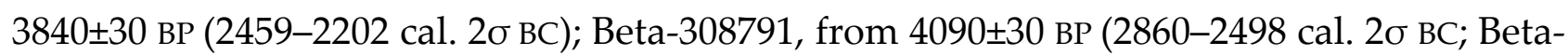

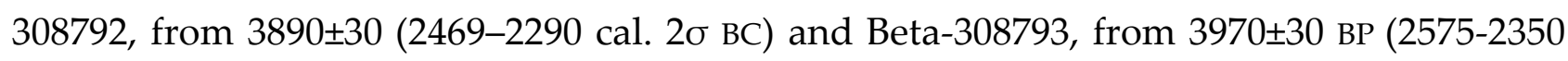

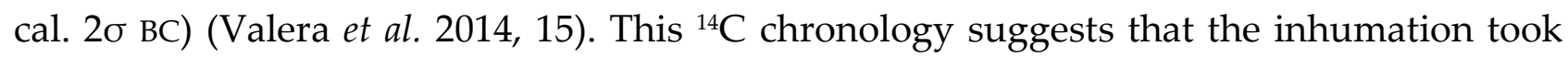
place in the Late Chalcolithic/Early Bronze Age, although the gold technology described for the foils is consistent with that of the Copper Age. Therefore, their manufacture in a previous phase of the site cannot be ruled out.

In Los Algarbes (Tarifa, Cadiz, Spain), a sheet of hammered gold appeared inside grave 5 (a hypogeum chamber), hemispherical in shape and decorated with geometric zigzag and chequered motifs, which may have covered another object (Posac Mon 1975) (Fig. 15e). Inside this grave there was a collective Chalcolithic burial that may have been reused in the Early Bronze Age, therefore there are doubts on whether the hemispherical sheet is from one period or the other - although it is normally counted as part of the golden productions from the Chalcolithic period.

In the case of other items, it is unclear whether they belong to the Copper Age or to the Bronze Age (Table 2). An example of this set of uncertain cases is that of S. Pedro de Estoril (Cascais, Lisbon, Portugal), a necropolis of artificial caves originally excavated in 1944 (Leisner et al. 1964) and later completely destroyed. In Cave no. 1 (with the remains of at least 28 people), an individual was found in association with four spiral rings of gold and other grave goods consisting of a number of smoothed bone buttons, a bell beaker cup with a base and an undecorated bell beaker vessel. One of these spiral rings was wrapped around one of the individual's phalanges, for which a radiocarbon date (Beta-178468) of 3790 $\pm 40 \mathrm{BP}$

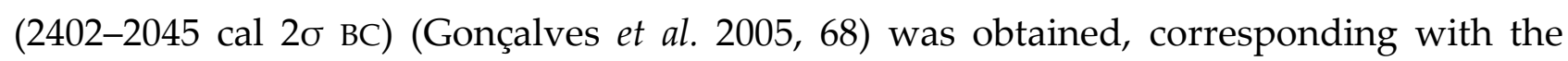
transition between the Copper Age and the Early Bronze Age. Both the ${ }^{14} \mathrm{C}$ chronology and the flat-section morphology suggest that these pieces were not manufactured within a strictly Chalcolithic metallurgical base, but at the beginning of the Bronze Age. 
Valencina de la Concepción is the site that has provided the greatest number of gold artefacts from the Iberian Copper Age (Fig. 16). The breakdown of these artefacts is shown in Table 3:
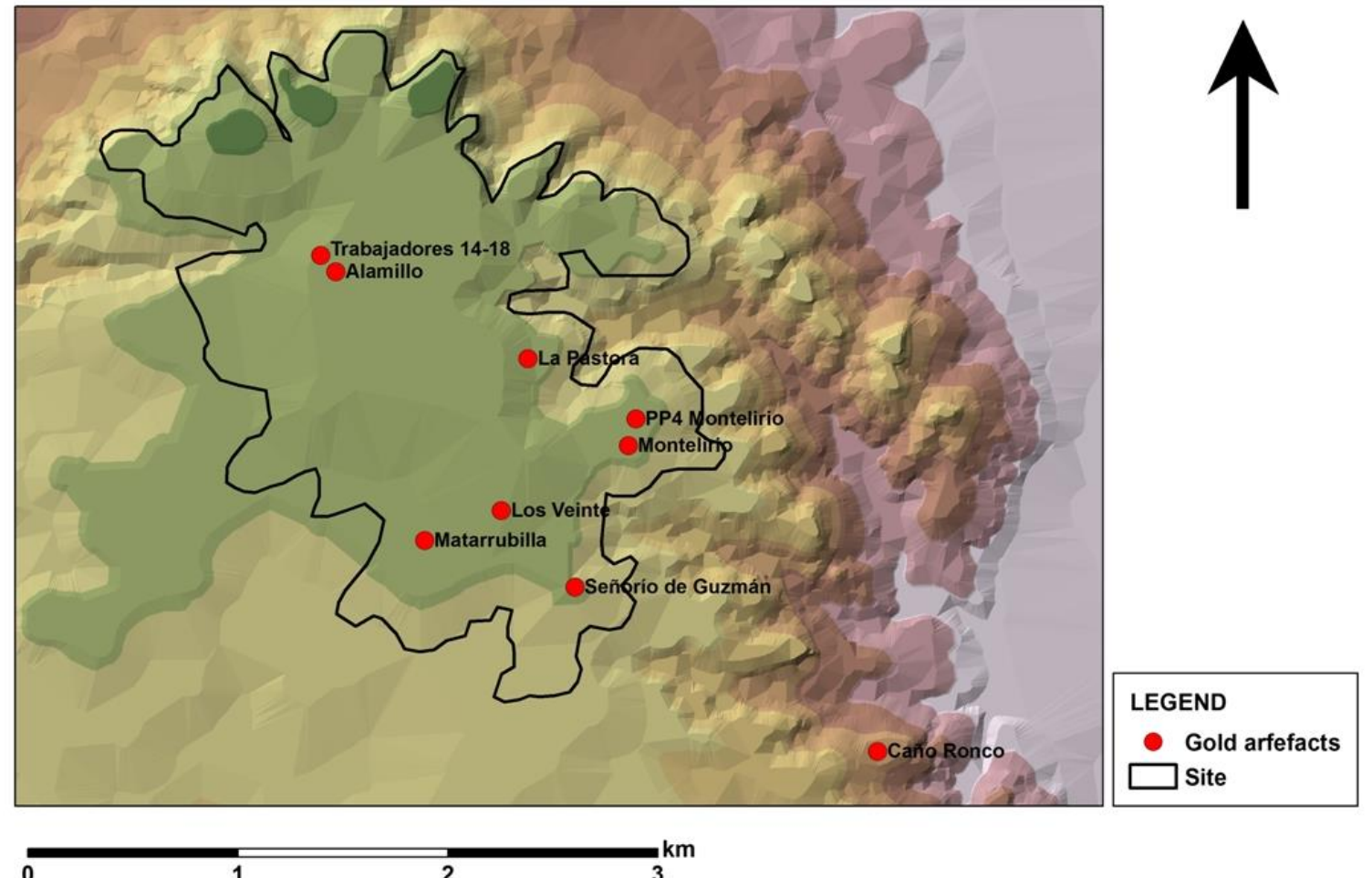

Figure 16. Location of all gold finds in the settlement of Valencina de la Concepción (Sevilla).

- Three undecorated sheets from the La Pastora tholos which, according to Almagro Basch (1962), were given to the National Archaeological Museum by the landowner of the property where the monument was located, together with the famous javelins (Perea Caveda 1991, 30; Perea Caveda et al. 2010, 56-61).

- A total of 13 sheet fragments (and several more tiny chips) were found in the Matarrubilla tholos, some of which are undecorated and some which display embossed decoration (chequered and linear motifs) similar to that of the piece from structure 10.029 (Perea Caveda 1991, 36) (Fig. 15g). These sheet fragments were discovered during the excavations carried out by F. Collantes de Terán, in association with 'dispersed human remains' in three groups distributed throughout the corridor, although they are currently all mixed together (Collantes de Terán 1969; Perea Caveda 1991, 30; Perea 
Caveda et al. 2010, 51-5). Four of these fragments are now on display at the permanent exhibition of the Archaeological Museum of Seville.

- At the beginning of the 1980s, in the Valencina sector called Los Veinte, located among the great megalithic structures of Ontiveros and Matarrubilla, the sieving of sediments from the remains of a possible funerary monument completely destroyed during land levelling work (of which only a large vertical stone remained in place) led to the discovery of some fragments of small sheets of gold like those from Matarrubilla and La Pastora. On these fragments, only a brief reference has been published (Fernández Gómez \& Oliva Alonso, 1983, 45).

- Gold artefacts were discovered in three of the graves excavated in the Señorío de Guzmán sector. In tomb 1, a sheet of gold decorated with linear and dotted motifs was found in association with fragments of a bell beaker cup and remains from lithic tools, as well as macrofaunal and malacofaunal remains (Arteaga Matute \& Cruz-Auñón Briones 2001, 647); in tomb 2, an undecorated sheet was discovered; in tomb 5, three tubular or cylindrical necklace beads were found (López Aldana et al. in press).

- In Calle Trabajadores, structure UE-56 (a circular pit $3.20 \mathrm{~m}$ in diameter) yielded a thin sheet of hammered gold, twisted into the shape of a lace (Fig. 15f) and weighing $4.5 \mathrm{~g}$, in connection with three large copper axes that were found barely $40 \mathrm{~cm}$ away (López Aldana \& Pajuelo Pando 2013, 163).

- In the excavations carried out in Calle Alamillo, in a feature described as a 'hut-floor' (López Aldana et al. 2001), a gold nugget was discovered, the only Iberian object of this kind ever found in a well-documented context. A recent publication refers to this piece as in connection with the metallurgical activities carried out in what is referred to as a 'metallurgical district' (Nocete Calvo et al. 2014, 694) of Valencina, claiming also that the nugget was found in spatial association with slag and crucibles used in copper smelting (Nocete Calvo et al. 2014, 694). These are erroneous references: first, because the PPMatarrubilla sector, described in a previous paper as Valencina's 'metallurgical district' (Nocete Calvo et al. 2008), is one kilometre away from Calle Alamillo (unless, of course it is assumed that the smelting 'district' of Chalcolithic Valencina was one kilometre in length); second, because the excavation report of Calle Alamillo only mentioned an 
'insignificant' amount of slag while no mention at all was made of crucibles: 'we cannot talk about metallurgical activity because the sample is so limited. We only have a copper needle found in level 8 and an insignificant amount of slag remains' (López Aldana et al. 2001,626$).^{6}$

- Among the numerous grave goods discovered in the megalithic structure of Caño Ronco (now destroyed and whose exact location has never been known) was a thin sheet of gold that covered the handle of a knife (the whereabouts of these materials is not known) (Cabrero García 1985; López Aldana et al. in press).

- In the large megalithic monument of Montelirio, four sheets, one of them decorated with embossed geometrical and eye-like motifs were discovered. To date, these item remain unpublished. ${ }^{7}$

In their recent paper concerning gold work in the Copper Age of south west Iberia, Nocete Calvo et al. $(2014,692)$ mention a piece of gold from a Valencina sector they refer to as 'Las Cabezas', quoting the report of the excavations carried out in the Cerro de La Cabeza tholos as a reference (Fernández Gómez \& Ruiz Mata 1978). However, in the Cerro de la La Cabeza excavation report, no mention is made of any gold artefact (Fernández Gómez \& Ruiz Mata 1978), ${ }^{8}$ which suggests that either Nocete Calvo et al. (2014) refer to another piece (certainly unpublished) from a sector of the site that is unknown to us, or this reference is a mistake.

Therefore, although as a whole it is difficult to offer a reliable and precise count of artefacts, given that in many cases only fragments have been found, the minimum number of gold objects/fragments found in Valencina to date would be 28, a figure that does not include the unknown number of fragments found at Los Veinte nor the numerous minute chips from Matarrubilla. This makes Valencina, together with Camino de las Yeseras, the Iberian Copper Age site with the (comparatively) largest collection of goldwork, the piece from structure 10.029 being the largest and most complete of the entire series.

\section{Context}

The lack of precise contextual information for the majority of these pieces (either because the excavations are old or because the published studies were more concerned with stylistic and/or technological matters) complicates the analysis of the social and ideological function 
of gold during the Copper Age. However, some important considerations can be made and, more importantly, these can be compared with those established with regard to the Bronze Age.

During the Copper Age, many gold artefacts were deposited in burial contexts, mainly megalithic structures and artificial caves. However, there are some important exceptions to this, particularly in Valencina de la Concepción, where the sheets from Calle Trabajadores and PP4-Montelirio were discovered in small negative features without any human remains. The fact that the largest and best preserved of all Iberian Chalcolithic gold artefacts, the sheet with 'oculi' from PP4-Montelirio, was found in a non-funerary structure is particularly interesting, given that it suggests that gold was not only used in burial activities. The implication of this is that gold may have had a wider and more generic ideological significance.

Copper Age gold artefacts do normally appear in collective megalithic graves in which it is normally impossible to associate specific artefacts with specific individuals (see Table 2). In contrast, artefacts from the Bronze Age usually appear associated with individuals that generally have clearly individualized grave goods. The 34 quantified gold artefacts for the Argaric culture of the Southeast were found in individual graves (MurilloBarroso 2013, 234). In the case of Valencina, the most important individual burial of a Copper Age high-status person published to date, which is that of the main chamber of structure 10.042-10.049, did not include any gold pieces among the large number of grave goods, but did include exotic raw materials such as ivory, flint, amber and cinnabar. This suggests the limited role of gold in the expression of the social status of high-ranking individuals, which is in accordance with what is known about copper objects. Although it is true that during the Copper Age some people seem to have been buried with personalized grave goods, it also seems clear that metal objects did not play a prominent role in exhibiting the status of high-standing individuals (Costa Caramé et al. 2010; Murillo-Barroso \& Montero-Ruiz 2012). The limited role of metal as an element of personal ostentation in these initial moments of metallurgy is also shown in the fact that copper-based metal objects were almost always tools or weapons/tools (Costa Caramé 2013), whereas copper-based personal ornaments are not documented until well into the Early Bronze Age, from c. 1800 cal BC 
onward (Murillo-Barroso \& Montero-Ruiz 2012). In Copper Age Valencina, the individual with the highest-ranking set of grave-goods (that found in the main chamber in tomb 10.042-10.049) displayed no metal artefacts and no goldwork.

The sheet from structure 10.029 cannot be directly related to a burial event, given that it is not associated with human remains. The pit in which it was found could perhaps be generally described as 'votive', given that it was used to deposit a number of other artefacts, both complete and fragmented, over a period of time that cannot be ascertained due to the absence of radiocarbon chronology. In this regard, structure 10.029 of PP4-Montelirio is similar to structures 3027 and 3370 from the site of La Orden-El Seminario (Huelva, Spain): pits with similar morphology and size, where an important collection of stone and bone idols were found, some of which had eyed motifs (González González et al. 2008; Vera Rodríguez et al. 2010).

Like its smaller counterparts from Las Canteras and Montelirio, the 'oculi' golden sheet from PP4-Montelirio seems to have been already broken when it was deposited, which could be connected to the practice of fragmentation (sensu Chapman 2000; Chapman \& Gaydarska 2007; 2009). Despite being broken, these gold objects may have played an important social role in symbolic episodes as votive depositions (Blanco-González 2014; Chapman 2000). Their original shape was not as important as their inherent meaning, as they had higher ideological than utilitarian social value among the community and therefore their use may well have continued after their breakage.

Therefore, from a contextual point of view, the sheet presented in this article seems to suggest that, during the Copper Age, gold was not restricted to burial practices, but it may have had a wider symbolic role. This coincides with what has been evidenced with the so-called Chalcolithic eye-motif 'idols', which appear in both domestic and burial contexts. It has been claimed that the eye motifs made on slate plaques and phalanges or large bones of large animals mainly appear in burials, while those represented on limestone or the anthropomorphic figurines are mainly found in 'domestic' environments (Hurtado Pérez 2009, 168; Maicas Ramos 2009, 129). If that statement were true, perhaps the eye motif could have had changing social meanings depending on the context of use. In the case of Valencina, the 'human figurines' appear to have been found in non-funerary (maybe 
'domestic') areas, as in PP-Matarrubilla, or maybe votive, as in La Perrera. In addition, the vast majority of the 'idols' were found in the northern area of the site (Hurtado Pérez 2013, figure 1), a fact that further questions the traditionally held belief that this settlement was once divided into two areas supposedly exclusively 'funerary' and 'domestic', something that we have questioned elsewhere-cf. discussion in García Sanjuán (2013).

\section{Composition and manufacture}

As stated above, the PP4-Montelirio foil is exceptional because of its low concentration of silver, which is unusual, given that alluvial gold normally has high levels of this metal. Usually, Chalcolithic gold pieces have a purity of c. 85-92 per cent with considerably higher concentrations of Ag that can even reach 50 per cent (Montero Ruiz \& Rovira Llorens 1991; Perea Caveda et al. 2010). In Iberia, the very few references to the composition of alluvial gold calculate the content of silver at around 10-13 per cent (Montero Ruiz \& Rovira Llorens 1991, 9), although there are exceptions, such as the gold nuggets of Casas de San Pedro (Badajoz) in which the silver content did not exceed 1 per cent (García Guinea et al. 2005, 27). In fact, data from Chalcolithic gold pieces that have already been analysed (Table 1) suggest that the majority have concentrations of silver ranging between 5 and 15 per cent, with only very few having levels below 1 per cent. They are limited to the PP4-Montelirio large decorated sheet, with 0.6 per cent Ag; a semi-circular sheet from Camino de las Yeseras (Madrid) with only 0.07 per cent Ag (Rovira et al. 2011, 306); pieces from Perdigões with silver levels from 0.5 to 4.9 per cent (Monge Soares et al. 2014); and a sheet from Alcalar 4 with c. 1 per cent (Hartmann 1982, 87). Another piece from the dolmen of La Veguilla (Salamanca) also has a very low silver content, only 0.2 per cent $\mathrm{Ag}$, as well as 0.01 per cent $\mathrm{Sn}$ and 0.01 per cent $\mathrm{Sb}$, but its chronology is somewhat later, from the Bronze Age (Rovira et al. 1997, 317). A gold torque with 4.2 per cent Ag and a Palmela-type arrowhead were also found in the same dolmen. From these levels of silver we shall now discuss those detected by SEM-EDS, which range between 1.6 per cent for the bead from the Grau del Tossal Gros (Soriano Llopis et al. 2012, 153) and 3.6 per cent for the sheet from the large megalithic monument of La Pastora, in Valencina (Perea Caveda et al. 2010, 57), but which, as mentioned previously, may be undervalued. The trend of gold objects with high silver 
content continued until the Iron Age, when a large number of alloys were documented with high levels of silver content to reduce the grade of gold (Montero Ruiz \& Rovira Llorens 1991), and refined gold also appeared (Hartmann 1982, 111), which was not technologically feasible during the Chalcolithic period.

The levels of copper in native gold are generally low, remaining below 1 per cent. The same occurs with artefacts unless they are intentional alloyed, which was not common in the Copper Age. All the artefacts have low levels of copper.

Provenance studies of prehistoric Iberian gold are rather scarce. An initial attempt to determine the origin consists of the classification of trace elements carried out by Hartmann (1982) and subsequently developed by others (Guerra et al. 2005; 2007), who mainly focused on the elements of the platinum group, particularly platinum $(\mathrm{Pt})$ and palladium $(\mathrm{Pd})$. Geographical and chronological trends were observed, although, given the absence of a geological identity of gold-bearing resources of the peninsula, one must be careful when stating the source of these based on trace elements.

The work of Guerra (2000; Guerra \& Roux 2002; Guerra et al. 2007) differentiates the districts of northern Iberia from those of the south with regard to the $\mathrm{Pt}, \mathrm{Pd}$, Sn and $\mathrm{Zn}$ proportions. Contrary to the districts of the north, those of the south are characterized by high levels of $\mathrm{Pt}$ and $\mathrm{Pd}$ and low concentrations of $\mathrm{Sn}$ and $\mathrm{Zn}$. Following this characterization, the PP4-Montelirio piece would coincide with the districts of the south while the materials from Cabezo Juré (Nocete Calvo et al. 2014) are more similar to the districts of the north, particularly because of the high levels of Sn. However, the isotopic signature of three of these samples (precisely those with higher contents of Sn) coincides with that of the Iberian Pyrite Belt, relating to areas such as Tharsis or the Tinto and Corumbel rivers, where the presence of cassiterite has also been documented (Nocete Calvo et al. 2014, 701). Given the little geological information available on Iberian placer deposits of gold, care must taken when pondering the source based on trace elements-bearing in mind also that the differentiation of the districts carried out by M.F. Guerra was not performed based on the geological characterization of the area, but instead on the trace elements of the coins produced in different mints, assuming these would have used local resources. 
The composition of trace elements of the piece from structure 10.029 does not differ significantly from the regulus found in Valencina, which also has low levels of Ag (1.8 per cent), although the sheet from PP4-Montelirio has higher levels of Mg (392 ppm) and Ti (811 ppm). According to Lead Isotope Analysis (LIA), the provenance assigned to the Valencina materials analysed by Nocete Calvo et al. $(2014,701)$ is the mineralization of the Central area of Osa Morena, in southwest Spain. We will have to wait for the ongoing LIA analysis of this piece to see if they coincide.

\section{Morphology, function and symbolism}

As shown in the brief summary outlined above, the vast majority of Iberian Chalcolithic gold artefacts are thin sheets (plain or decorated), some of which would have been attached to other objects, perhaps rigid supports or textiles. The concave sheet of Los Algarbes (Fig. 15e), which is $5.5 \mathrm{~cm}$ wide, may have covered the spherical knob of a cane or a symbolic object; the sheet from Villaverde del Río held together a series of copper arrowheads (Fig. 15d); one of the sheets from Marroquíes Bajos was found around an anthropomorphic figurine; the perforations described earlier clearly suggest that the large sheet of structure 10.029 from the PP4-Montelirio de Valencina sector would have been sewn or attached to another material, which has also been suggested with regard to the sheet from the Las Canteras tholos (Hurtado Pérez 2009, 151) (Fig. 15b).

Excluding the large diadem from Los Murciélagos (from the Neolithic period) and various pieces of doubtful chronology (as they could belong to the Bronze Age), golden ornaments clearly associated to specific individuals are almost unheard of in the Copper Age-with the possible exception of the Camino de las Yeseras diadem. In the case of Valencina, the only cases of possible personal ornaments are the three beads from tomb 5 of the Señorío de Guzmán sector, although the publication in which this piece is presented for the first time (López Aldana et al. in press) does not include drawings or photographs, so it is impossible to evaluate their possible functional nature. In contrast, all the known Early Bronze Age gold artefacts are bracelets, pendants or rings generally associated with specific individuals - that is, objects clearly created to fulfil a personal ostentation function (Delibes de Castro \& Montero Ruiz 1999; Perea Caveda 1991). 
The comparative appraisal of the morphology and decoration suggests, as does the contextual data presented above, that the sheet of Valencina's structure 10.029 was an object of sacred, cultic and/or votive character, connected with ideas of collectiveness and cultural identity. This is in contrast with what we know about Early Bronze Age gold objects, which had a stronger function as individual markers of social position and social identity. The Copper Age symbolism of gold seems to refer to the domain of the cosmovision, whereas that of the Bronze Age refers to society. There are three main arguments to support this:

a) Shape. With regard to its shape, this piece is similar to those made on another material that have sometimes been described as 'sandal' or 'sandal-shaped' idols. Pieces of this type made of bone, ivory or stone and with perforations along the edges have been documented in Almizaraque (Almería, Spain) (Maicas Ramos 2007, fig. III.74) (Fig. 17) and in grave 12 at Los Millares (Almería, Spain) (Leisner \& Leisner 1943, 25, plate 11.20; Schuhmacher 2012) in the southeast of Spain, as well as in artificial cave no. 1 at Alapraia (Cascais, Lisbon, Portugal) (Gonçalves et al. 2005, 183-5). The asymmetry noted for the PP4-Montelirio item can also be seen in the pieces from Almizaraque and Alapraia - in the latter case half of the piece is shorter than the other (in this case, given the lack of decoration it seems to be harder to establish which is the 'upper' part and which is the 'lower' part). This asymmetry is due to the use of an odd number of strips.

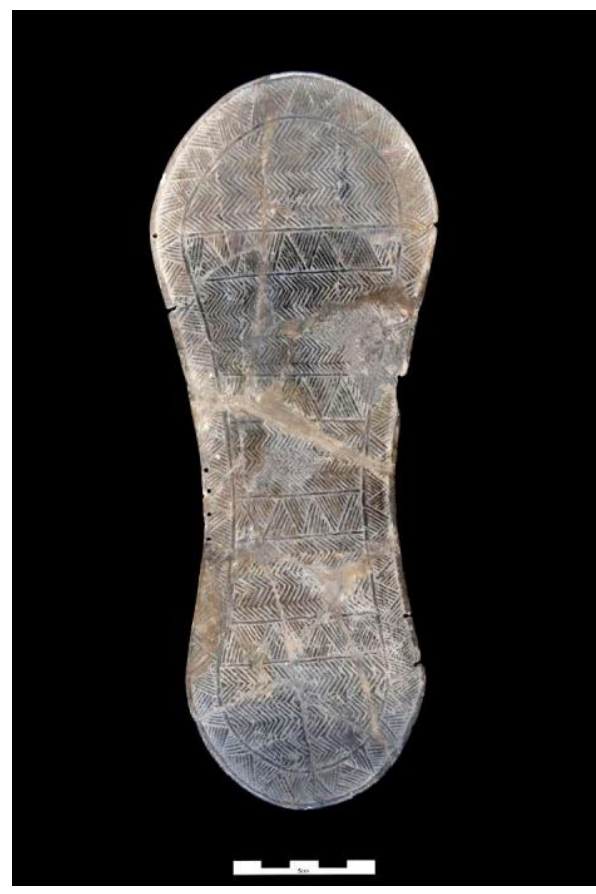

Figure 17. Ivory sandal shape found in Almizaraque (Almería), decorated with zigzag motifs and perforations. 
b) Perforations. Another argument to connect the gold plaque of structure 10.029 with the 'sandal-shaped' pieces is the lateral perforations. The ivory plaque discovered in tomb 12 of Los Millares has a series of V-shaped perforations on the front side (Leisner \& Leisner 1943, 25), as does that of Almizaraque. The same applies to the carved ivory plaque from structure 10.042-10.049 of Valencina's PP4-Montelirio sector, which we have recently interpreted as the rigid support of a dagger sheath (García Sanjuán et al. 2013, 621). The fragment from a piece of ivory found in the Matarrubilla tholos, which shows perforations around the edges (Schuhmacher et al. 2013, 497, fig. 2), could also be a piece of this sort. The fact that, just as the 'sandal-shaped' pieces are decorated on one side only, the PP4-Montelirio gold sheet is polished on one side lends further support to the idea that there was a functional unicity among all these objects. The sheet from structure 10.029 was designed to be attached to another support so that it could be looked at from the front, like a sacred image. Its very thinness $(0.04 \mathrm{~mm})$ supports the idea of the item being attached to some supporting material and being quite carefully handled and protected. If it was primarily conceived to be exhibited, its materiality in terms of colour and reflectiveness would have played an important role.

c) Decoration. The decorative motifs on the piece from structure 10.029 are similar to those that appear in countless examples of Chalcolithic 'idols' and figurines throughout southern Iberia. This is particularly the case of the so-called 'decorated plaques' or 'plaque idols' made of schist or slate ${ }^{9}$ (Fig. 18a). Both the chevrons and the zigzag lines, as well as the eye-motifs, of course, are well-documented in these supports (Bueno Ramírez 1992; Bueno Ramírez 2010; Lillios 2008) (Fig. 18). Similarities should be noted in the layout of the decoration with horizontal superimposed strips and separated by frames, as well as the possible graphic and iconographic relationship between the dotted pyramid-like motifs on the gold sheet of the PP4-Montelirio sector and the large number of triangles on the plaques (and which also appear on some of the Valencina carved ivory pieces). This dotted decoration is also common in symbolically decorated ceramics, as shown in the Portuguese cases of Monte de Outeiro (Beja) (Leisner 1965, plate 128.1), Anta de Olival da Pega 1 (Évora) (Leisner \& Leisner 1959, plate 41) or Anta Grande de Zambujeiro (Évora) (Fig. 18c) (Gonçalves 
1999), where two fragments of gold sheets decorated with zigzag motifs were found (Parreira \& Pinto 1980).

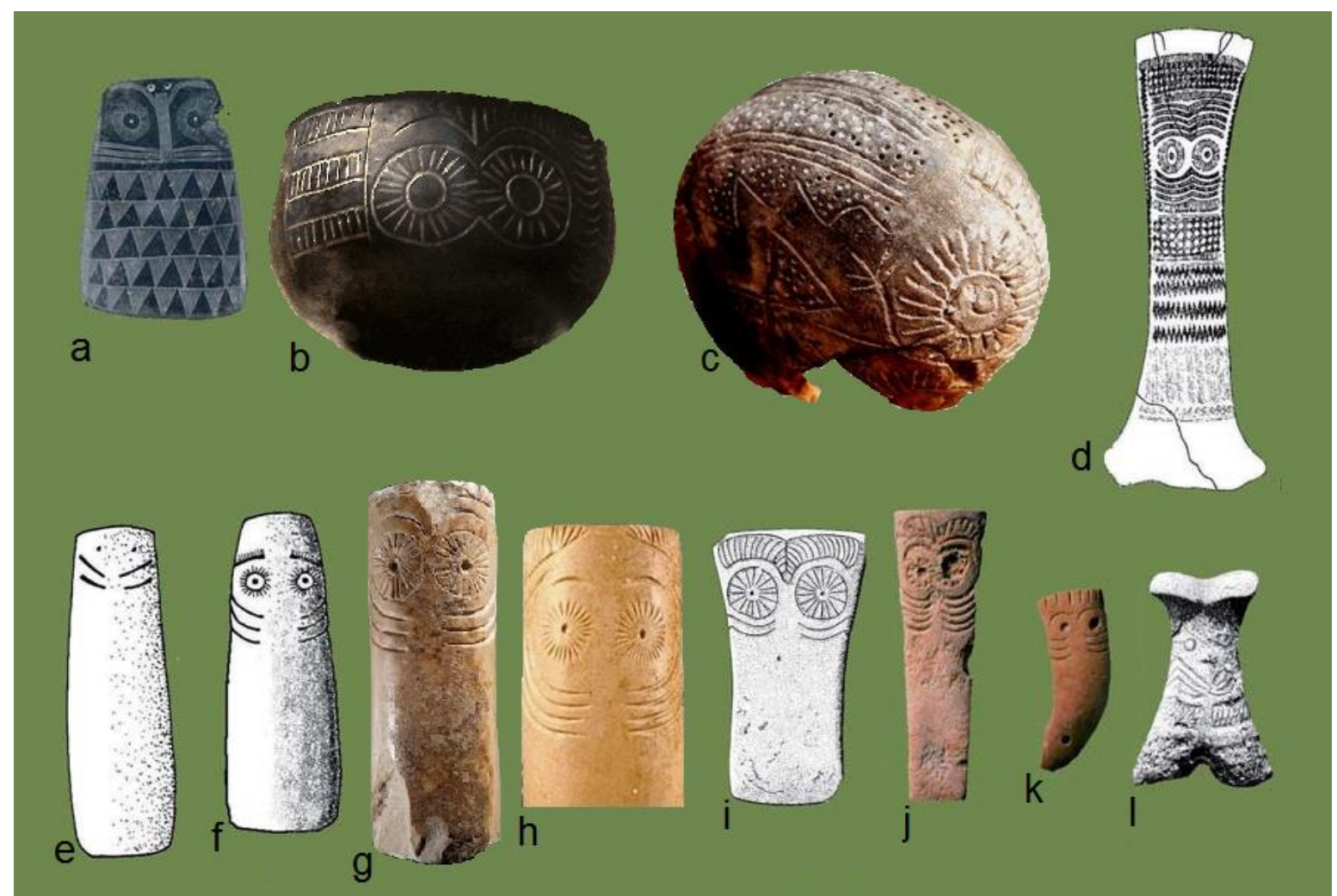

Figure 18. Idols with eye motifs from southern Iberia manufactured on different materials. a) Slate plaque from Valencina de la Concepción (Sevilla); $b$ \& c) Pottery bowls from Los Millares (Almería) and Anta Grande de Zambujeiro (Évora); d) Bone from Almizaraque (Almería); e-g) Limestone idols from Estremadura, Algarve (Portugal) and Conquero (Huelva); h) Marble idol from Cerro de las Vacas (Lebrija, Sevilla); i) Limestone idol from La Pijotilla (Badajoz); $j$ and $k$ ) Pottery idols from Los Millares (Almería); l) Phalanx idol. Figures are not to scale.

The four eye motifs are, of course, the most important graphical motif for connecting the gold sheet of structure 10.029 with 'symbolic' objects such as idols and figurines. Given that the eye motifs appeared on a wide variety of supports and formats during the Copper Age, it has been suggested that regional variations in their style may be understood as an expression of ethnic, cultural and social identities (Hurtado Pérez 2008; 2009). Based on the stylistic differences of the eyes, it has been suggested that perhaps four groups existed in southwest Iberia (Hurtado Pérez 2008, 9): Portuguese Estremadura (with a simplified representation: the eye is reduced to two points, as shown in Fig. 18e); the Portuguese Algarve (with radial lines outside the ocular circles and on the curved incisions of the 
eyebrows: Fig. 18f); the lower Guadalquivir valley (there are radiuses engraved inside the ocular circles, eyebrows and facial markings: Fig. 18g) and the middle Guadiana basin (with the same elements as the Guadalquivir modality but with wide, framed eyebrows filled in with parallel lines: Fig. 18i).

The eye motif of the gold sheets from PP4-Montelirio and Las Canteras would correspond to the stylistic group of the lower Guadalquivir and middle Guadiana basins, given that there are radial lines inside the circumference of the eye. More specifically, the only eye representations on gold from the entire Iberian peninsula appear specifically in the province of Seville, including the finds of Las Canteras and Valencina (Montelirio and PP4Montelirio sectors). This is particularly significant and may signify the expression of the cultural identity of the human groups living in this region in the third millennium BC.

\section{Conclusions}

Based on the new data obtained from the exceptional gold piece from sector PP4-Montelirio of Valencina, and its subsequent appraisal within the known artefacts from the rest of Iberia, a series of provisional conclusions can be drawn with regard to the social and ideological role of this material in the third millennium BC.

1) Its manufacture is consistent with the technology of the Chalcolithic period, which did not require a great deal of sophistication (at least if compared to Iron Age goldwork involving welding, granulating, etc.). In order to achieve a large, thin and heavily decorated sheet, a high level of knowledge and skill concerning hammering and embossing techniques was, however, needed. With regard to the raw materials, the purity of the gold used is particularly notable. The low levels of copper are consistent with an alluvial origin for the gold (as with the rest of the gold Chalcolithic pieces documented in the Iberian peninsula). Although one would expect higher levels of silver, areas of alluvial gold with low levels of silver have also been documented (Badajoz). Unfortunately, given the limited characterization of Iberian geological gold, and since lead isotope results are not yet available, we cannot provide any further 
information with regard to the origin of the raw material the PP4-Montelirio piece was made of.

2) Given its context, shape and decoration, the sheet from structure 10.029 may have formed part of an icon or a sacred object that was decorated with the eye-solar motif that is omnipresent in Iberian Copper Age imagery. Moreover, the inherent properties of gold in terms of colour, reflectivity, shine and nobility have largely determined its embedding in the ritual sphere in prehistory (Primas 1995). If the base of this sheet had been made of ivory, which cannot be completely ruled out given the similarities in the peculiar 'sandal-shaped' outline, this could be an association of ivory and gold similar to that used in the Aegean Bronze and Iron Ages for the creation of important sacred images ('chryselephantine'). This functional interpretation may be extended to some of the other gold sheets, the development of which has never been verified given their reduced size, rolled-up shape or high degree of fragmentation.

3) During the Copper Age, gold objects had a generic symbolic function, related to symbols and representations of divine or supernatural beings, which can be seen in other media used for symbolic expression. This is in sharp contrast with the reality of the Early Bronze Age, when gold went on to be used to manufacture personal adornments aimed at aggrandizing specific individuals. In this respect, the difference established by Brown $(1984,36)$ between 'power-authority' and 'social hierarchization' could be applicable to the use of gold in, respectively, the Chalcolithic and Bronze Age periods. This is also suggested by the fact that, while gold objects during the Bronze Age lacked decoration, a number of gold sheets from the Chalcolithic period include heavy decorations similar to that of other objects generally considered 'symbolic' or 'ideo-technical' (ceramics, plaques or idols), which would appear to materialize the world view, the social ideology and/or collective/regional identities that were prevalent in the Copper Age.

4) The association of gold as a raw material with the iconography of an 'eye motif' consisting of a circle with radiating lines is consistent with the traditional interpretation made of the latter in solar terms. In European late prehistory, gold has been associated with concepts related to the sun, given its shine and colour (the 
Trundholm sun chariot or the Nebra disc would be two of the clearest examples). Gold has been related on a number of occasions to dual cosmologies presided over by the sun (masculine) and the moon (feminine), which would be materially represented by gold and silver (Lechtman 1993; Perea Caveda 2012). Due to their colour and reflectiveness, gold and silver have also been related respectively to the sun and the moon in South American cosmovisions (Hosler 2010). Although silver is not documented in Iberia until the Middle Bronze Age, and this dichotomy cannot be extrapolated, the pieces from the province of Seville (Valencina and Las Canteras) suggest a complex polisemic gold-eye-sun symbolic association.

5) During the Copper Age gold does not seem to have had a main social function of individual ostentation, but instead appears to have been used in combination with other objects that may have been related to specific ritual or funerary ceremonies. This is also suggested by the fact that the largest and most complete gold artefact of Chalcolithic Iberia was not found in a tomb, forming part of a series of grave goods, but in a pit, where, perhaps, it was deposited as a votive offering. Individual graves with gold personal ornaments and beaker grave-goods could be understood as a transition from the more collective Copper Age ideology and the more individualized Bronze Age one, a change which surely took a large span of time.

6) The differences in social organization between the Copper Age and the Bronze Age, clearly reflected in the characterization and use of copper-based metal objects (Costa Caramé \& García Sanjuán 2009; Costa Caramé et al. in press; Murillo-Barroso \& Montero Ruiz 2012) are also reflected in gold and silver artefacts. During the first centuries of the Bronze Age, personal adornments were made of gold and then deposited in individual tombs. Around 1800 cal BC there was an increase in the consumption of silver, which seemed to some extent to replace the use of gold in funerary assemblages (Costa Caramé et al. in press). It was also during this time that the first copper adornments appeared (Murillo-Barroso \& Montero Ruiz 2012). This must be related to other changes that appear in funerary practices and which are a sign of deeper social changes. It is also around $1800 \mathrm{cal} \mathrm{BC}$ that in the southeast some 
children's graves were furnished with prestige objects, while halberds become more scarce and long blade swords appear (Castro Martínez et al. 1994, 94, 97 \& n. 41).

In short, although the evolution of the relationship between metal and funerary rituals during the Copper and Bronze Age is complex, recent research has revealed some general trends: from the greater presence of symbolic elements in the collective burials of the Copper Age, with metal (copper and gold) being somewhat unrelated to the exhibition of personal social status, towards the more personalized grave goods of the Early Bronze Age often in individual tombs (although not universally, since there is an important casuistry of reusing old collective burial chambers), with a greater presence of weapons and gold objects from c. 2300-2200 cal BC and a rise in personal copper and silver-based adornment items around c. 1800 cal. BC (Costa Caramé et al. in press).

\section{Notes}

1. The diadem from the Los Murciélagos cave (Albuñol, Granada), weighing $44.5 \mathrm{~g}$ and measuring $53 \mathrm{~cm}$, is from the Neolithic period.

2. March 2014.

3. Particularly the decorated vessel that was found on the lower level of the main chamber of megalithic monument 10.042-10.049 or the engraved tusk discovered in the upper level of the same structure (García Sanjuán et al. 2013).

4. A Hitachi S-3400n (Type II) Scanning Electron Microscope was used, equipped with an Energy-Dispersive X-ray Spectroscopy (EDS), Bruker Quantax 4010 (SDD) from the IH-CSIC R\&D archaeology laboratories.

5. The elemental composition was obtained with the LA-ICP-MS in the laboratories of the General Services of the Geochronology and Isotope Geochemistry laboratory of the University of the Basque Country. A Thermo Fisher Scientific model X Series 2 mass spectrometry quadrupole was used, with a New Wave ablation laser, UP213 model equipped with a solid state $213 \mathrm{~nm} \mathrm{Nd:YAG.} \mathrm{The} \mathrm{measurements} \mathrm{were} \mathrm{taken} \mathrm{in} \mathrm{damp}$ conditions (wet ablation), therefore a Peltier refrigerated nebulizer chamber was used 
and a PFA microconcentric nebulizer. The methodology issues are outlined in Kovacs et al. (2009).

6. The absence of crucibles at Calle Alamillo has been corroborated to us by Ana Pajuelo Pando, one of the excavators, through personal communication.

7. We thank Álvaro Fernández Flores for this reference.

8. By direct communication with Dr F. Fernández Gómez, ex-director of the Archaeological Museum of Seville: he confirmed that no gold artefacts were discovered during this excavation.

9. In Valencina de la Concepción a very limited number of plaque idols (only four) has been found (Hurtado Pérez 2013, 319).

\section{Acknowledgements}

This research has been carried out as part of the project 'Comparative Analysis of Social and Economic Dynamics in the Late Prehistory of Central and Southern Iberia (6th to 2nd millennia BC): The Southwest (HAR2009-14360-C03-03)' funded by the Spanish Government. It is also supported by a Marie Curie Intra European Fellowship within the 7th European Comunity Framework Programme ("Society Metallurgy and Innovation: The Iberian Hypothesis" - SMITH project, PN623183). We would like to thank the staff the Archaeology Museum in Seville, and particularly the director, Ana Navarro Ortega, for their help and support in the study of the PP4-Montelirio finds. We thank Ana Pajuelo Pando and Fernando Fernández Gómez for their valuable help in making an inventory of the gold items found at Valencina. We would also like to thank Ignacio Montero Ruiz for making possible the study of the PP4-Montelirio gold foil in the SEM of the IH-CSIC Laboratory of Archaeometry, and Óscar García-Vuelta for his operation of the equipment. We are indebted to Alicia Perea Caveda for her comments on prehistoric and protohistoric goldwork and to Javier Sánchez Palencia for giving us access to the Laser Ablation ICP-MS equipment of the País Vasco University. We must also thank Gonzalo Aranda Jiménez, Primitiva BuenoRamírez and the two anonymous reviewers for their useful comments on a previous draft of this paper. 
Mercedes Murillo-Barroso Institute of Archaeology

University College London 31-34 Gordon Square London WC1H OPY $U K$ m.murillo-barroso@ucl.ac.uk

Manuel Eleazar Costa Caramé Department of Prehistory and Archaeology University of Seville Maria de Padilla s/n. 41004 Seville Spain eleazarcosta@us.es Marta Díaz-Guardamino Uribe Department of Archaeology University of Southampton Southampton SO17 1BF $U K$ M.M.Diaz-Guardamino-Uribe@soton.ac.uk Leonardo García Sanjuán Department of Prehistory and Archaeology University of Seville Maria de Padilla s/n. 41004 Seville Spain 


\section{References}

Alday, A., 1992. La primera industria del oro en el País Vasco y La Rioja. Munibe 43, 43-55.

Almagro Basch, M., 1962. El ajuar del Dolmen de La Pastora de Valentina del Alcor (Sevilla). Sus paralelos y su cronología. Trabajos de Prehistoria del Seminario de Historia Primitiva del Hombre 5, 5-35.

Aparicio, J., J.V. Martínez, D. Vines \& D. Campillo, 1981. Las raíces de Bañeres. Valencia: Uniresidad de Valencia

Arteaga Matute, O. \& R. Cruz-Auñón Briones, 2001. Las nuevas sepulturas prehistóricas (tholoi) y los enterramientos bajo túmulos (tartesios) de Castilleja de Guzmán (Sevilla). Excavación de Urgencia 1996, in Anuario Arqueológico de Andalucía 3. Seville: Junta de Andalucía, 64051.

Bertz, 1995

Belo, R., L. Trindade, O. da Veiga Ferreira, 1961. Gruta da Cova da Moura (Torres

Vedras). Comunicações dos Serviços Geológicos de Portugal 45, 391-418.

Blanco-González, A., 2014. Tracking the social lives of things: biographical insights into Bronze Age pottery in Spain. Antiquity 88: 441-55.

Blasco, C. \& P. Ríos, 2010. La función del metal entre los grupos campaniformes. Oro versus cobre. El ejemplo de la Región de Madrid. Trabajos de Prehistoria 67, 359-72.

Bueno Ramírez, P., 2010. Ancestros e imágenes antropomorfas muebles en el ámbito del megalitismo occidental: las placas decoradas, in Ojos que nunca se cierran. Ídolos en las primeras sociedades campesinas, 39-78, eds. C. Cacho Quesada, R. Maicas Ramos, E. Galán Domingo \& J.A. Martos. Madrid: Museo Arqueológico Nacional 
Bueno Ramírez, P., 1992. Les plaques décorées alentéjaines: approache de leur étude et analyse, L'Anthropologie 96 (2-3), 573-604.

Brown, J.A., 1984. The search for ranking in prehistoric burials, in The Archaeology of Death, eds. R. Chapman, I.A. Kinnes \& K. Randsborg. Cambridge: Cambridge University Press, 25-37.

Cabrero García, R., 1985. El sepulcro megalítico de Cano Ronco (Camas, Sevilla) y su vinculación con el yacimiento calcolítico de Valencina de la Concepción. Prehistoria 1, 1-15.

Cáceres Puro, L.M., F. Muñiz Guinea, J. Rodríguez Vidal, J.M. Vargas Jiménez \& T. Donaire Romero, 2014. Marine bioerosion in rocks of the prehistoric tholos of La Pastora (Valencina de la Concepción, Seville, Spain): archaeological and palaeoenvironmental implications. Journal of Archaeological Science 41, 435-46.

Cacho Quesada, C., C. Papi Rodes, A. Sánchez-Barriga \& F. Alonso Mathias, 1996. La cestería de cuerda de la Cueva de los Murciélagos (Albuñol, Granada), in Homenaje al Profesor Manuel Fernández-Miranda, eds. M.A. Querol Fernández \& T. Chapa Brunet. (Complutum Extra 6. Tomo I.) Madrid: Universidad Complutense de Madrid, 105-22.

Castro Martínez, P.V., R.W. Chapman, S. Gili Suriñach et al., 1994. Tiempos sociales de los contextos funerarios argáricos. Anales de Prehistoria 9-10, 77-105.

Chapman, J., 2000. Fragmentation in Archaeology. London: Routledge.

Chapman, J. \& B. Gaydarska, 2007. Parts and Wholes: Fragmentation in Prehistoric Context. Oxford: Oxbow.

Chapman, J. \& B. Gaydarska, 2009. The fragmentation premise in archaeology: from the Paleolithic to more recent times, in The Fragment: An Incomplete History, ed. W. Tronzo. Los Angeles (CA): Getty Research Institute, 131-53.

Collantes de Terán, F., 1969. El dolmen de Matarrubilla, in Tartessos y sus Problemas. Actas del V Simposio internacional de Prehistoria Peninsular. Barcelona: Universidad de Barcelona, 4762.

Comendador, B., 1997. Los inicios de la Metalurgia en el noroeste de la Península Ibérica. $\mathrm{PhD}$ Thesis. University of Santiago de Compostela.

Costa Caramé, M.E., 2009. Jaén, in Las Grandes Piedras de la Prehistoria. Sitios y Paisajes Megalíticos de Andalucía, eds. L. García Sanjuán, \& B. Ruiz González. Seville: Junta de Andalucía Sevilla, 184-97.

Costa Caramé, M., 2013. La actividad metalúrgica en Valencina de la Concepción (Sevilla): problemática y situación actual de la investigación, in El Asentamiento Prehistórico de Valencina de la Concepción (Sevilla): Investigación y Tutela en el 150 Aniversario del Descubrimiento de La Pastora, eds. L. García Sanjuán, J.M. Vargas Jiménez, V. Hurtado Pérez, T. Ruiz Moreno \& R. Cruz-Auñón Briones. Seville: Universidad de Sevilla, 459-69. 
Costa Caramé, M.E. \& L. García Sanjuán, 2009. El papel ideológico de las producciones metálicas en la Edad del Bronce: El caso del Suroeste de la Península Ibérica (c. 2200-1500 cal ANE). Cuadernos de Prehistoria y Arqueología de la Universidad de Granada 19, 195-224.

Costa Caramé, M.E., M. Díaz-Zorita Bonilla, L. García Sanjuán \& D. Wheatley, 2010. The Copper Age settlement of Valencina de la Concepción (Seville, Spain): demography, metallurgy and spatial organization. Trabajos de Prehistoria 67(1): 87-118.

Costa Caramé, M.E., L. García Sanjuán, I. Montero-Ruiz \& M. Murillo-Barroso, forthcoming. The role of metal productions in the ideology of Early Bronze Age societies (c. 2200-1500 cal $\mathrm{BCE})$ in Southern Iberia, in Making Metals and Moulding Society: a Global Perspective on the Emergence of Bronze Age Social Complexity, eds. Th. Rehren et al. Oxford: Oxbow.

Delibes de Castro, G., 1977. El vaso campaniforme en la meseta norte española. (Studia Archaeologica 46.) Valladolid: Universidad de Valladolid.

Delibes de Castro, G. \& I. Montero Ruiz (eds.), 1999. Las primeras etapas metalúrgicas en la Península Ibérica II. Estudios regionales. Madrid: Instituto Universitario Ortega y Gasset, Ministerio de Cultura.

Fernández Gómez, F. \& D. Oliva Alonso, 1983. Las Edades del Metal, in Historia de Sevilla y Su Provincia, ed. A.M. Flores. Seville: Gever, 33-65.

Fernández Gómez, F. \& D. Ruiz Mata, 1978. El tholos del Cerro de la Cabeza en Valencina de la Concepción (Sevilla). Trabajos de Prehistoria 35, 193-221.

García-Alix, A., F.J. Jiménez Espejo, J.A. Lozano Rodríguez, et al., 2013. Anthropogenic impact and lead pollution throughout the Holocene in southern Iberia. Science of The Total Environment 449, 451-60.

García Guinea, J., V. Correcher, R.M. Rojas, J.L.G. Fierro, C. Fernandez-Martin, P. López-Arce \& S. Rovira-Llorens, 2005. Chemical tracers in archaeological and natural gold: Aliseda Tartessos treasure and new discovered nuggets (SW Spain). Gold Bulletin 38(1), 23-8.

García Sanjuán, L., 2013. El asentamiento de la Edad del Cobre de Valencina de la Concepción: estado actual de la investigación, debates y perspectivas, in El Asentamiento Prehistórico de Valencina de la Concepción (Sevilla): Investigación y Tutela en el 150 Aniversario del Descubrimiento de La Pastora, eds. L. García Sanjuán, J.M. Vargas Jiménez, V. Hurtado Pérez, T. Ruiz Moreno \& R. Cruz-Auñón Briones. Seville: Universidad de Sevilla, 21-59. García Sanjuán, L. \& L. Murillo-Barroso, 2013. Social complexity in Copper Age southern Iberia (c. 3200-2200 cal BC): reviewing the 'state' hypothesis at Valencina de la Concepción (Seville, Spain), in The Prehistory of Iberia: Debating Early Social Stratification and the State, eds. M. Cruz Berrocal, L. García Sanjuán \& A. Gilman. New York (NY): Routledge, $119-40$. 
García Sanjuán, L., M. Luciañez Triviño, T. Schuhmacher, D.W. Wheatley \& A. Banerjee, 2013. Ivory craftsmanship, trade and social significance in the southern Iberian Copper Age: the evidence from the PP4-Montelirio sector of Valencina de la Concepción (Seville, Spain). European Journal of Archaeology 16(4), 610-35.

Gonçalves, V.S., 1999. Catálogo da Exposição Reguengos de Monsaraz, Territórios Megalíticos. Lisbon: Museu Nacional de Arqueologia.

Gonçalves, V.S., M. Magalhaes Ramalho, S. Daveau, et al. (eds.), 2005. Cascais Há 5000 anos.

Cascais: Câmara Municipal de Cascais.

Góngora y Martínez, M., [1868] 1991. Antigüedades Prehistóricas de Andalucía. (Facsimile edition.) Granada: Universidad de Granada.

González González, B., J.A. Linares Catela, J.C. Vera Rodríguez \& D. González Batanero, 2008. Depotfund Zylinderförmiger Idole Des 3. Jts. V. Chr. aus La Orden-Seminario (Prov. Huelva). Madrider Mitteilungen 49, 1-28.

Guerra, M.F., 2000. Em busca da origem do ouro dos Visigodos através dos seus elementos traço, in Homenagem a Mário Gomes Marques, eds. M.C. Hipólito, D.M. Metcalf, J.M.P. Cabral \& M. Crusafont i Sabater. Sintra: Instituto de Sintra, 223-51.

Guerra, M.F. \& C. Roux, 2002. L'or de la péninsule ibérique de l'invasion à la reconquista. Revue d'Archéométrie 22, 219-32.

Guerra, M.F., T. Calligaro, M. Radtke, I. Reiche \& H. Riesemeier, 2005. Fingerprinting ancient gold by measuring Pt with spatially resolved high energy Sy-XRF. Nuclear Instruments and Methods in Physics Research B 240, 505-11.

Guerra, M.F., T. Calligaro \& A. Perea, 2007. The treasure of Guarrazar: tracing the gold supplies in the Visigothic Iberian peninsula. Archaeometry 49(1), 53-74.

Hartmann, A., 1982. Prähistoriche Goldfunde aus Europa II. Spektralanalysche Untersuchungen und deren Auswertung. (Studien zu den Anfängen der metallurgie 5.). Berlin: Gebr. Mann.

Heleno, M., 1942. Gruta artificial da Ermegeira. Ethos 2, 449-462.

Hernando Gonzalo, A., 1983. La orfebrería durante el Calcolítico y el Bronce Antiguo en la Península Ibérica, Trabajos de Prehistoria 40, 85-138.

Hosler, D., 1994. The Sounds and Colors of Power: The Sacred Metallurgical Technology of Ancient West Mexico. Cambridge (MA): MIT Press.

Hunt Ortiz, M., M.A. Ontalba Salamanca, I. Ortega-Feliu, B.M. Gómez Tubío, M.A. Respaldiza, A. Fernández Flores \& A. Rodríguez Azogue, 2010. Los elementos de oro prehistóricos y protohistóricos de las últimas campañas de excavación (2002-2005) en el yacimiento de El Carambolo (Camas, Sevilla), in El Carambolo: 50 Años de un Tesoro, eds. M.L. De La Bandera Romero, \& E. Ferrer Albelda. Seville: Universidad de Sevilla, 335-44. 
Hurtado Pérez, V., 2008. Ídolos, estilos y territorios de los primeroscampesinos en el sur peninsular, in Acercándonos al pasado. Prehistoria en 4 actos, eds. C. Cacho Quesada, R. Maicas Ramos, J.A. Martos \& M.I. Martínez. Madrid: Museo Arqueológico Nacional y CSIC, 1-11. Hurtado Pérez, V., 2009. Representaciones simbólicas, sitios, contextos e identidades territoriales en el suroeste Peninsular, in Ojos que nunca se cierran. Ídolos en las primeras sociedades campesinas,eds. C. Cacho Quesada, R. Maicas, E. Galán \& J.A. Martos. Madrid: Ministerio de Cultura, 137-98.

Hurtado Pérez, V., 2013. Los ídolos del asentamiento de Valencina de la Concepción: una revisión, in El Asentamiento Prehistórico de Valencina de la Concepción (Sevilla): Investigación y Tutela en el 150 Aniversario del Descubrimiento de La Pastora, eds. L. García Sanjuán, J.M. Vargas Jiménez, V. Hurtado Pérez, T. Ruiz Moreno \& R. Cruz-Auñón Briones. Seville: Universidad de Sevilla, 311-27.

Hurtado Pérez, V. \& F. Amores Carredano, 1984. El tholos de las Canteras y los enterramientos del Bronce en la Necrópolis de El Gandul. Cuadernos de Prehistoria de la Universidad de Granada 9: 147-74.

Hurtado Pérez, V. \& M.A. Hunt Ortiz, 1999. Extremadura, in Las Primeras Etapas Metalúrgicas en la Península Ibérica. Volumen II. Estudios Regionales, eds. G. Delibes de Castro \& I. Montero Ruiz. Madrid: Instituto Universitario Ortega y Gasset, 241-74.

Kovacs, K., S. Schlosser, S.P. Staub, A. Schmiderer, E. Pernicka \& D. Günther, 2009. Characterization of calibration materials for trace element analysis and fingerprint studies of gold using LA-ICP-MS. Journal of Analytical Atomic Spectrometry 24, 476-83.

Lechtman, H., 1993. Technologies of power-the Andean case, in Configurations of Power in Complex Society, eds. J.S. Henderson \& P.J. Netherly. New York (NY): Cornell University Press, 244-80.

Leisner, V., 1965. Die Megalithgräber der Iberischen Halbinsel: Der Westen, I/3. Berlin: Walter de Gruyter.

Leisner, G. \& V. Leisner, 1943. Die Megalithgräber der Iberischen Halbinsel. Der Süden. (Römisch-Germanische Forschungen 17). Berlin: Walter de Gruyter.

Leisner, G. \& V. Leisner, 1959. Die Megalithgräber der Iberischen Halbinsel: Der Westen, I/2.. Berlin: Walter de Gruyter.

Leisner, V., A. Paço \& L. Ribeiro, 1964. Grutas Artificiais de Sao Pedro de Estoril. Lisbon: Fundaçao Calouste Gulbenkian.

Lillios, K., 2008. Heraldry for the Dead: Memory, Identity and the Engraved Stone Plaques of Neolithic Iberia. Austin (TX): University of Texas Press. 
López Aldana, P. \& A. Pajuelo Pando, 2013. La secuencia ocupacional durante el III milenio ANE en c/ Trabajadores 14-18 (Valencina de la Concepción, Sevilla), in El Asentamiento Prehistórico de Valencina de la Concepción (Sevilla): Investigación y Tutela en el 150 Aniversario del Descubrimiento de La Pastora, eds. L. García Sanjuán, J.M. Vargas Jiménez, V. Hurtado Pérez, T. Ruiz Moreno \& R. Cruz-Auñón Briones. Seville: Universidad de Sevilla, 157-69.

López Aldana, P.M., A. Pajuelo Pando, J.C. Mejías-García \& M.R. Cruz-Auñón Briones, in press. Variabilidad funeraria en las sociedades del III milenio en el sector Señorío de Guzmán de Valencina-Castilleja (Sevilla), in Actas do II Congresso Internacional sobre Arqueologia de Transição: O Mundo Funerário.

López Aldana, P.M., O. Sánchez Liranzo, A. Pajuelo Pando, S. Ruiz, A. Vera Rodríguez, I. García \& M. Velasco, 2001. Excavación de urgencia de una estructura habitacional en Valencina de la Concepción (Sevilla). Anuario Arqueológico de Andalucía/1997, Tomo II. Seville: Junta de Andalucía, 623-33.

López, C. \& J.M. Tudanca, 1996. Excavaciones en el sepulcro megalítico de Collado de Mallo (Trevijano, La Rioja). Campaña de 1995. Informe preliminar. Estrato 7, 14-24.

Luciañez Triviño, M., L. García Sanjuán \& T. Schuhmacher, T. 2014. Restaurierung von archäologischem Elfenbein am Beispiel von vier chalkolithischen Elfenbeinobjekte aus der Siedlung von Valencina de la Concepción (Sevilla). Restaurierung und Archäologie 6, 71-87. Luezas, R. \& S. Rovira, 2004. El enterramiento eneolítico de Valdehiguero (Ribafrecha, La Rioja): estudio analítico de un elemento de adorno. Berceo 146, 259-265.

Maicas Ramos, R., 2007. Industria Ósea y Funcionalidad: Neolítico y Calcolítico en la Cuenca de Vera (Almería). Madrid: Consejo Superior de Investigaciones Científicas, CSIC.

Maicas Ramos, R., 2009. Los ojos que todo lo ven: Oculados del Sureste, in Ojos que nunca se cierran. Ídolos en las primeras sociedades campesinas, eds. C. Cacho Quesada, R. Maicas, E. Galán \& J.A. Martos. Madrid: Ministerio de Cultura, 115-36.

Monge Soares, A.M., M.C. Alves, J.C. Frade, et al., 2014. Bell Beaker gold foils from Perdigões (Southern Portugal) - manufacture and use, in Proceedings of the 39th International Symposium for Archaeometry, Leuven (2012), eds. R.B. Scott, D. Braekmans, M. Carremans \& P. Degryse. Leuven: KU Leuven, Centre for Archaeological Sciences, 120-24.

Montero Ruiz, I. \& S. Rovira Llorens, 1991. El oro y sus aleaciones en la orfebrería prerromana. Archivo Español de Arqueología, 64(163-164), 7-21.

Mora Molina, C., 2011. Las Estructuras de la Edad del Cobre del Sector PP4-Montelirio del Sitio Arqueológico de Valencina de la Concepción-Castilleja de Guzmán (Sevilla). Masters dissertation, University of Seville. 
Mora Molina, C., L. García Sanjuán, J. Peinado Cucarella \& D. Wheatley, 2013. Las estructuras de la Edad del Cobre del Sector PP4-Montelirio del sitio arqueológico de Valencina de la Concepción-Castilleja de Guzmán (Sevilla), in El Asentamiento Prehistórico de Valencina de la Concepción (Sevilla): Investigación y Tutela en el 150 Aniversario del Descubrimiento de La Pastora, eds. L. García Sanjuán, J.M. Vargas Jiménez, V. Hurtado Pérez, T. Ruiz Moreno \& R. Cruz-Auñón Briones. Seville: Universidad de Sevilla, 261-79.

Morán Hernández, E., R. Parreira \& J. Santa Rita, 2007. Alcalar: Monumentos Megalíticos.

Roteiros de Arqueologia Portuguesa 10. Lisbon: IGESPAR.

Murillo-Barroso, M., 2013. Producción y Consumo de Plata. Un Análisis Comparativo entre la Sociedad Argárica y los Primeros Asentamientos Orientalizantes en el Sur de la Península Ibérica. Granada: Universidad de Granada.

Murillo-Barroso, M. \& L. García Sanjuán, 2013. El pomo de ámbar de la estructura 10.042-10.049 del sector PP4-Montelirio del asentamiento de Valencina de la Concepción (Sevilla), in El Asentamiento Prehistórico de Valencina de la Concepción (Sevilla): Investigación y Tutela en el 150 Aniversario del Descubrimiento de La Pastora, eds. L. García Sanjuán, J.M. Vargas Jiménez, V. Hurtado Pérez, T. Ruiz Moreno \& R. Cruz-Auñón Briones, 511-19.

Murillo-Barroso, M. \& I. Montero-Ruiz, 2012. Copper ornaments in the Iberian Chalcolithic.

Technology versus social demand. Journal of Mediterranean Archaeology 25(1), 53-73.

Nocete Calvo, F., 2001. Tercer Milenio ANE. Relaciones y Contradicciones Centro-Periferia en el Valle del Gualdalquivir. Barcelona: Bellaterra.

Nocete Calvo, F., G. Queipo de Llano, R. Sáenz, et al., 2008. The smelting quarter of Valencina de la Concepción (Seville, Spain): the specialised copper industry in a political centre of the Guadalquivir valley during the Third Millennium BC (2750-2500 BC). Journal of Archaeological Science 35, 717-32.

Nocete Calvo, F., R. Sáez, M. Rodríguez Bayona, et al., 2014. Gold in the southwest of the Iberian peninsula during the 3rd millennium BC. Journal of Archaeological Science 41, 691-704.

Parreira, R. \& C.V. Pinto, 1980. Catálogo da Exposição Tesouros da Arqueologia Portuguesa no Museu Nacional de Arqueologia e Etnologia. Lisbon: Instituto Português de Museus.

Perea Caveda, A., 1991. Orfebrería Prerromana. Arqueología del Oro. Madrid: Comunidad de Madrid.

Perea Caveda, A., 2012. El género de los objetos. Variaciones sobre orfebrería argárica, in La Arqueología funeraria desde una perspectiva de género. II Jornadas Internacionales de Arqueología y Género en la UAM, ed. L. Prados Torreira. (Colección Estudios 145.) Madrid: Universidad Autónoma de Madrid, 79-99. 
Perea Caveda, A., Ó. García-Vuelta \& C. Freire, 2010. El Proyecto AU. Estudio Arqueométrico de la producción de oro en la Península Ibérica. (Bibliotheca Praehistorica Hispana 28.) Madrid: Consejo Superior de Investigaciones Científicas.

Pérez Arrondo, C.L., 1983. La cultura megalítica en la margen derecha del Ebro. Cuadernos de Investigación, Historia 1, 51-63.

Posac Mon, C., 1975. Los Algarves (Tarifa). Una necrópolis de la Edad del Bronce. Noticiario Arqueológico Hispánico 4, 85-120.

Primas, M., 1995. Gold and silver during the 3rd mil. Cal. BC, in Prehistoric Gold in Europe, eds. Morteani, G. and J.P. Northover. Boston-London: Dordrecht, 77-93.

Robles Carrasco, S., 2011. Análisis Bioarqueológico de tres Contextos-Estructuras Funerarias del Sector PP4 - Montelirio del yacimiento de Valencina de la Concepción - Castilleja de Guzmán (Sevilla). Masters dissertation, University of Seville.

Robles Carrasco, S. \& M. Díaz-Zorita Bonilla, 2013. Análisis bioarqueológico de tres contextosestructuras funerarias del sector PP4-Montelirio del yacimiento de Valencina de la Concepción-Castilleja de Guzmán (Sevilla), in El Asentamiento Prehistórico de Valencina de la Concepción (Sevilla): Investigación y Tutela en el 150 Aniversario del Descubrimiento de La Pastora, eds. L. García Sanjuán, J.M. Vargas Jiménez, V. Hurtado Pérez, T. Ruiz Moreno \& R. Cruz-Auñón Briones. Seville: Universidad de Sevilla, 369-86.

Rogerio-Candelera, M.A., L.K. Herrera, A.Z. Miller, et al., 2013. Allochthonous red pigments used in burial practices at the Copper Age site of Valencina de la Concepción (Sevilla, Spain): characterisation and social dimension. Journal of Archaeological Science 40(1), 279-90.

Rovira Hortalà, M.C., F. Borrell, M. Oliva, M. Saña, O. Vicente \& G. Alcalde, 2014. Early gold remains in the north-east of the Iberian Peninsula, in Metals of power - Early gold and silver, eds. H. Harald Meller, R. Risch, \& E. Pernicka, E. Halle: Tagungen des Landesmuseums für Vorgeschichte Halle, 257-267.

Rovira, S., C. Blasco, P. Ríos, I. Montero \& J. Chamón, 2011. La Arqueometalurgia, in Yacimientos Calcolíticos con Campaniforme de la Región de Madrid: Nuevos Estudios, eds. C. Blasco, C. Liesau \& P. Ríos. (Patrimonio Arqueológico de Madrid 6.) Madrid: Universidad Autónoma de Madrid, 291-311.

Rovira, S., I. Montero \& S. Consuegra, 1997. Las primeras etapas metalúrgicas en la península Ibérica. I. Análisis de materiales. Madrid: Fundación Orte-ga y Gasset.

Sangmeister, E. \& H. Schubart, 1981. Zambujal. Die Grabungen 1964bis 1973. Mainz: Verlag Philipp von Zabern. 
Schuhmacher, T.X. 2012. Die Elfenbeinobjekte des Chalkolithikums und der Frühen Bronzezeit auf der Iberischen Halbinsel. Interdisziplinäre Studien zu Herkunft, Austausch, Verarbeitung und sozialer Bedeutung von Elfenbein. Iberia Archaeologica 16,2. Mainz: Philipp Von Zabern

Schuhmacher, T., A. Banerjee, W. Dindorf, F. Nocete Calvo \& J.M. Vargas Jiménez, 2013. Los marfiles del yacimiento de Valencina en el contexto del Calcolítico del Suroeste peninsular, in El Asentamiento Prehistórico de Valencina de la Concepción (Sevilla): Investigación y Tutela en el 150 Aniversario del Descubrimiento de La Pastora, eds. L. García Sanjuán, J.M. Vargas Jiménez, V. Hurtado Pérez, T. Ruiz Moreno \& R. Cruz-Auñón Briones. Seville: Universidad de Sevilla, 496-510.

Serna González, M.R., 1989. El vaso campaniforme en el valle del Guadalquivir, in Tartessos. Arqueología Protohistórica del Bajo Guadalquivir, ed. M.E. Aubet Semmler. Sabadell: AUSA, 47-84.

Soriano Llopis, I., J. Soler Subils \& N. Soler i Masferrer, 2012. ¿La primera orfebrería del nordeste de la Península Ibérica? Nuevas aportaciones a partir de la cuenta áurea de Cau del Tossal Gros (Torroella del Montgrí, Baix Empordà, Girona). Trabajos de Prehistoria 69(1), 149-61. Valera, A.C., A.M. Silva \& J.E. Márquez Romero, 2014. The temporality of perdigões enclosures: absolute chronology of the structures and social practices. Spal 23, 11-26Vera Rodríguez, J.C., J.A. Linares Catela, M.J. Armenteros Lojo \& D. González Batanero, 2010. Depósitos de ídolos en el poblado de La Orden-Seminario de Huelva: espacios rituales en contexto habitacional, in Ojos que Nunca se Cierran. Ídolos en las Primeras Sociedades Campesinas, eds. C. Cacho Quesada, R. Maicas Ramos, E. Galán Domingo \& J.A. Martos. Madrid: Museo Arqueológico Nacional, 199-242.

Van der Lingen, E., L. Cornish, S. Taylor, R. Süss \& S. Grice, 2004. Metallography and Microstructures of Precious Metals and Precious Metal Alloys, in Metallography and Microstructures, ed. G.F. Vander Voort. ASM Handbook, Vol 9, Cleveland: ASM International, 860-876

\section{Author biographies}

Mercedes Murillo-Barroso holds a post-doctoral Marie Curie Intra European Fellowship (SMITH project, PN623183) within the 7th European Community Framework Programme at University College London. Her research focuses on early metallurgy in Iberia integrating archaeometallurgical analyses with social issues such as the relationship between the development of metallurgy and the evolution of social complexity. 
Manuel Eleazar Costa Caramé held a pre-doctoral fellowship in the University of Seville (Spain). His doctoral thesis is focused on analysing the metallurgy from the third and second millennia BC in southwestern Iberia and its social, economic and symbolic repercussions. At the present, he works as an archaeologist in a private company.

Marta Díaz-Guardamino Uribe is a part time Lecturer in Archaeology at the University of Southampton (UK). Her research focuses on the later prehistory of the Iberian peninsula, particularly on early monumental sculpture, megalithic monuments and landscapes. Her research interests include the application of social theory and digital technologies to archaeological enquiry.

Leonardo García Sanjuán is a Senior Lecturer in Prehistory at the Department of Prehistory and Archaeology of the University of Seville (Spain). His research focuses on social complexity, funerary practices and megalithic monuments, as well as archaeological survey and spatial analysis in the third and second millennia BC.

Coronada Mora Molina is a professional archaeologist. She holds a degree in History (2010) as well as a Masters degree in Archaeology (2011) from the University of Seville. She has excavated various megalithic monuments in the province of Huelva (Spain) and is currently participating in the study of the PP4-Montelirio sector of the Valencina de la Concepción Copper Age settlement. 
Table 1. Composition analyses of Iberian gold finds.

\begin{tabular}{|c|c|c|c|c|c|c|c|c|c|c|c|c|c|c|c|c|c|c|c|c|c|c|c|c|}
\hline \multicolumn{25}{|c|}{ Analytical Technique: LA-ICP-MS. Results in ppm; $\mathrm{Au}, \mathrm{Ag}$ and $\mathrm{Cu} \%$ wt. } \\
\hline Site & Sample Table note 1 & $\mathrm{Au}$ & $\begin{array}{l}\text { A } \\
\mathrm{g}\end{array}$ & $\begin{array}{l}\mathbf{C} \\
\mathbf{u}\end{array}$ & Mg & $\mathrm{Ti}$ & V & $\mathrm{Cr}$ & Mn & Fe & Co & $\mathrm{Ni}$ & Zn & As & Se & Pd & Cd & Sn & $\mathrm{Sb}$ & Te & $\mathbf{P t}$ & $\mathrm{Pb}$ & Bi & Reference \\
\hline PP4-Montelirio & $(5)$ & 99,0 & 0,6 & 0,15 & 392,5 & 811,6 & 3,1 & $11^{*}$ & 8,2 & 187 & & & & 0,3 & & 51,4 & & 9,5 & 17 & 10,0 & 44,3 & 15 & 9,8 & \\
\hline \multirow{4}{*}{$\begin{array}{l}\text { Cabezo Juré, Huelva } \\
\text { (MIDAS) }\end{array}$} & 378 Sheet (3) & 89,7 & 10,0 & 0,01 & 2,3 & $1,5^{* *}$ & & & 2,9 & 155 & & 2,0 & & 3,6 & 6,6 & $1^{* *}$ & & 2430 & 27 & 1,9 & & 14 & & Nocete et al. 2014, 698 \\
\hline & 435 Sheet (3) & 89,7 & 10 & 0,01 & 24 & 19,0 & & & 11,3 & 484 & & 1,3 & & 5,1 & 8,8 & 1,1 & & 2371 & 26 & 1,8 & & 13 & & Nocete et al. 2014, 698 \\
\hline & 434 Sheet (3) & 88,4 & \begin{tabular}{|l|l|}
11,1 \\
\end{tabular} & 0,01 & 10,1 & 4,3 & & & 6,8 & 249 & & 2,8 & & 8,4 & 14,6 & & & 3387 & 23 & 2,1 & & 21 & & Nocete et al. 2014, 698 \\
\hline & 506 Sheet (6) & 94,7 & 4,6 & 0,14 & 80,5 & 3038 & $9,7^{* * *}$ & & 67,3 & 404 & 1,3 & 29,1 & 94 & 19,6 & 25 & 1,4 & 0,6 & 227 & 5,2 & 11,5 & 4,2 & 14 & 0,4 & Nocete et al. 2014, 698 \\
\hline \multirow{2}{*}{$\begin{array}{c}\text { Valencina de la } \\
\text { Concepción, Sevilla } \\
\text { (MIDAS) }\end{array}$} & 487 Sheet (3) & 85,3 & 14,4 & 0,17 & $2,9^{*}$ & & & & 1,4 & 747 & & & & 3,4 & 5,6 & 28 & & 1,1 & 1,1 & 2,5 & & & 10 & Nocete et al. 2014, 698 \\
\hline & 505 regulus (3) & 98,1 & 1,8 & 0,10 & & $12^{*}$ & & & 8,5 & 57 & & 2,0 & $20^{* *}$ & $1,1^{*}$ & $3,6^{*}$ & & & 5,2 & 8,4 & & & $6^{* *}$ & & Nocete et al. 2014, 698 \\
\hline \multicolumn{25}{|c|}{ Analytical Technique: OES. Results \% wt. } \\
\hline \multicolumn{4}{|c|}{ Site } & & \multicolumn{6}{|c|}{ Sample } & $\mathbf{A u}$ & & $\mathrm{Ag}$ & \multicolumn{2}{|c|}{$\mathrm{Cu}$} & \multicolumn{3}{|l|}{ Sn } & $\mathbf{N i}$ & & $\mathbf{B i}$ & \multicolumn{3}{|r|}{ Reference } \\
\hline \multirow{4}{*}{\multicolumn{4}{|c|}{$\begin{array}{l}\text { Dolmen de Matarrubilla. Valencina de la Concepción, } \\
\qquad \text { Sevilla }\end{array}$}} & & \multicolumn{6}{|c|}{ Au1881 Decorated sheet } & & & c. 3 & \multicolumn{2}{|c|}{0,04} & \multicolumn{3}{|l|}{0,005} & & & & \multicolumn{3}{|c|}{ Hartmann 1982,87} \\
\hline & & & & & \multicolumn{6}{|c|}{ Au1882 Decorated sheet } & & & $3-4$ & \multicolumn{2}{|c|}{0,085} & \multicolumn{2}{|l|}{$\mathrm{Nd}$} & $\operatorname{Tr}$ & & & & \multicolumn{3}{|c|}{ Hartmann 1982,87} \\
\hline & & & & & \multicolumn{6}{|c|}{ Au1883 Decorated sheet } & & & c. 2 & \multicolumn{2}{|c|}{0,084} & $\mathrm{Nd}$ & & $\operatorname{tr}$ & & & & & Har & tmann 1982,87 \\
\hline & & & & & & Au1 & 384 Smal & Shee & & & & & c. 3 & 0,08 & & $\mathrm{Nd}$ & & & & & & & Har & tmann 1982,87 \\
\hline & & & & & & & $\mathrm{u} 2477 \mathrm{~B}$ & ead & & & & & c. 3 & 0,038 & & $\mathrm{Nd}$ & & & & & & & Har & tmann 1982,87 \\
\hline Penha Ver & e, Sintra, Portuga & & & & & $\mathrm{Au} 247$ & 8 Sheet 1 & ragm & & & & & $3-5$ & 0,03 & & $\mathrm{Nd}$ & & & & & & & Har & tmann 1982,87 \\
\hline Cañada Hon & a de Gandul. Su & & & & & & u $1763 \mathrm{St}$ & rips & & & & & 9 & 0,04 & & 0,096 & & & & & & & Har & tmann 1982,87 \\
\hline Canada Hon & la de Ganduil, Sev & & & & & & $1764 \mathrm{St}$ & rips & & & & & 9 & 0,03 & & 0,021 & & & & & & & Har & tmann 1982,87 \\
\hline Cañada del Carrasca & l, Mairena del Alc & cor, Se & villa & & & & $\mathrm{u} 1765 \mathrm{St}$ & rips & & & & & 6 & 0,04 & & 0,38 & & & & & & & Har & tmann 1982,87 \\
\hline Cueva de los Murc & élagos, Albuñol, & Grana & & & & & $1815 \mathrm{Di}$ & adem & & & & & 6 & 0,05 & & 0,13 & & & & & & & Har & tmann 1982,87 \\
\hline Alcalar 4 & Portiman Portugal & & & & & $\mathrm{Au} 265$ & 3 Decora & ted sh & neet & & & & $3-5$ & 0,34 & & $\mathrm{Nd}$ & & 0,01 & & & & & Har & tmann 1982,87 \\
\hline Alcalar 4, & ortımao, Portuga & & & & & & $\mathrm{u} 2654 \mathrm{~S}$ & trip & & & & & c. 1 & 0,13 & & $\mathrm{Nd}$ & & & & & & & Har & tmann 1982,87 \\
\hline Alcalar 11, & ortimao, Portuga & & & & & $\mathrm{Au} 30 \mathrm{C}$ & 6 Decora & ted sh & neet & & & & c. 3 & 0,04 & & $\mathrm{Nd}$ & & & & & & & Har & tmann 1982,87 \\
\hline Senhora de Lu & , Rio Maior, Port & tugal & & & & & u $2593 \mathrm{~S}_{1}$ & iiral & & & & & 14 & c. 0,0 & & 0,93 & & & & & & & Har & tmann 1982,89 \\
\hline & & & & & & Au 26 & 39 Lamir & har be & & & & & 13 & 0,07 & & 0,44 & & & & & & & Har & tmann 1982,89 \\
\hline & & & & & & $\mathrm{Au} 26$ & 40 Lamir & ar be & & & & & 8 & 0,06 & & 0,47 & & & & & & & Har & tmann 1982,89 \\
\hline & & & & & & $\mathrm{Au} 26$ & 41 Lamir & ar be & & & & & 13 & 0,04 & & 0,041 & & & & & & & Har & tmann 1982,89 \\
\hline Grota da Ermegeir & a, Torres Vedras, & Portug & & & & & $2642 \mathrm{Pel}$ & idant & & & & & 15 & c. 0,0 & & 0,12 & & & & & & & Har & tmann 1982,89 \\
\hline & & & & & & & $2643 \mathrm{Pel}$ & dant & & & & & c. 9 & 0,08 & & 0,52 & & & & & & & Har & tmann 1982,89 \\
\hline & & & & & & $\mathrm{Au} 26$ & 44 Lamir & ar be & & & & & c. 8 & 0,08 & & 0,52 & & & & & & & Har & tmann 1982,89 \\
\hline & & & & & & $\mathrm{Au} 26$ & 45 Lamir & ar be & & & & & c. 8 & 0,05 & & 0,38 & & & & & & & Har & tmann 1982,89 \\
\hline Quinta do An & 0, Palmela 1, Port & tugal & & & & & $\mathrm{u} 2647 \mathrm{~S}$ & iral & & & & & 13 & 0,03 & & 0,081 & & & & & & & Har & tmann 1982,89 \\
\hline Quinta do Anjo, $\mathrm{F}$ & almela 4 , Tabe note $2 \mathrm{P}$ & Portug & & & & $\mathrm{Au} 26$ & 48 Lamir & ar be & & & & & 8 & 0,03 & & 0,29 & & & & & & & Har & $\operatorname{tmann} 1982,89$ \\
\hline
\end{tabular}




\begin{tabular}{|c|c|c|c|c|c|c|c|c|c|}
\hline & Au 2649. Laminar bead. & & 7 & 0,04 & 0,11 & & & & Hartmann 1982,89 \\
\hline & Au 2650. Laminar bead. & & 8 & 0,04 & 0,12 & & & & Hartmann 1982,89 \\
\hline Quinta do Anjo, Palmela 3, Portugal & $\mathrm{Au}$ 2651. Sheet. & & c. 10 & 0,04 & 0,18 & & & & Hartmann 1982, 89 \\
\hline Cova da Moura, Torres Vedras, Portugal & Au 2906. Perforated sheet & & 9 & 0,05 & 0,14 & & & & Hartmann 1982,89 \\
\hline Zambujal, Torres Vedras, Portugal & Au 4581. Laminar bead & & c. 9 & 0,07 & 0,28 & & & & Hartmann 1982, 91 \\
\hline \multirow{3}{*}{ Cerro de la Virgen 1, Orce, Granada } & Au 1818. Spiral. & & 12 & 0,89 & 0,015 & 0,05 & & & Hartmann 1982, 91 \\
\hline & Au 1820. Frag. Perforated sheet & & 7 & 0,18 & 0,060 & & & & Hartmann 1982, 91 \\
\hline & $\mathrm{Au}$ 1822. Spiral & & c. 13 & 2,1 & 0,019 & & & & Hartmann 1982, 101 \\
\hline \multicolumn{10}{|c|}{ Analytical Technique: ED-XRF. Results \% wt. } \\
\hline Site & Sample & $\mathrm{Au}$ & $\mathrm{Ag}$ & & $\mathrm{Cu}$ & $\mathrm{Fe}$ & Sn & $\mathrm{Sb}$ & Ref. \\
\hline Valdehiguero, Logroño & PA6816 Sheet & 93,83 & 6,16 & & nd & & & & Rovira et al. 1997,245 \\
\hline Collado de Mallo, Logroño & PA6820 Sheet & 90,07 & 9,57 & & 0,36 & & & & Rovira et al. 1997,247 \\
\hline \multirow{8}{*}{ Collado Palomero I, Logroño } & PA6837 Sheet & 92,99 & 7,01 & & & & & & Rovira et al. 1997, 247 \\
\hline & PA6838 Sheet & 93,82 & 6,18 & & & & & & Rovira et al. 1997, 247 \\
\hline & PA6849 Sheet & 87,03 & 12,96 & & & & & $\operatorname{Tr}$ & Rovira et al. 1997, 247 \\
\hline & PA6840 Sheet & 92,87 & 7,12 & & & & & & Rovira et al. 1997, 247 \\
\hline & PA6841 Sheet & 93,08 & 6,90 & & & & & & Rovira et al. 1997, 247 \\
\hline & PA68342 Sheet & 93,16 & 6,83 & & & & & & Rovira et al. 1997, 247 \\
\hline & PA6843 Sheet & 92,85 & 6,96 & & 0,18 & & & & Rovira et al. 1997,248 \\
\hline & PA6844 Sheet & 92,76 & 7,23 & & & & & & Rovira et al. 1997,248 \\
\hline \multirow{18}{*}{$\begin{array}{c}\text { Camino de las Yeseras, San Fernando de Hen ares, } \\
\text { Madrid }\end{array}$} & PA12861 Perforated sheet. & 91,3 & 8,67 & & & & 0,04 & & Rovira et al. 2011, 306 \\
\hline & PA12862 Perforated sheet. & 91,5 & 8,45 & & & & 0,02 & & Rovira et al. 2011, 306 \\
\hline & PA12862a Semicircular sheet & 99,9 & 0,07 & & & & & $\operatorname{Tr}$ & Rovira et al. 2011, 306 \\
\hline & PA12909 Laminar bead. & 93,0 & 6,94 & & & & 0,02 & 0,02 & Rovira et al. 2011, 306 \\
\hline & PA13222 Laminar bead. & 93,5 & 6,38 & & & & 0,05 & 0,03 & Rovira et al. 2011, 306 \\
\hline & PA13219 Laminar bead. & 93,7 & 6,23 & & & & 0,02 & 0,01 & Rovira et al. 2011, 306 \\
\hline & PA13223 Laminar bead. & 92,9 & 7,06 & & & & 0,05 & 0,01 & Rovira et al. 2011, 306 \\
\hline & PA13221 Laminar bead. & 93,5 & 6,48 & & & & 0,01 & 0,02 & Rovira et al. 2011, 306 \\
\hline & PA12866 Laminar bead. & 92,9 & 7,01 & & & & 0,02 & 0,02 & Rovira et al. 2011, 306 \\
\hline & PA12865 Laminar bead. & 92,5 & 7,46 & & & & 0,03 & 0,01 & Rovira et al. 2011, 306 \\
\hline & PA12908 Laminar bead. & 93,2 & 6,78 & & & & 0,02 & $\operatorname{tr}$ & Rovira et al. 2011, 306 \\
\hline & PA12902 Laminar bead. & 93,4 & 6,53 & & & & & 0,02 & Rovira et al. 2011, 306 \\
\hline & PA12906 Laminar bead. & 93,2 & 6,77 & & & & 0,02 & 0,04 & Rovira et al. 2011, 306 \\
\hline & PA12905 Laminar bead. & 93,1 & 6,86 & & & & 0,04 & 0,03 & Rovira et al. 2011, 306 \\
\hline & PA13220 Laminar bead. & 93,8 & 6,07 & & & & 0,03 & 0,02 & Rovira et al. 2011, 306 \\
\hline & PA12901 Laminar bead. & 92,6 & 7,40 & & & & & $\operatorname{tr}$ & Rovira et al. 2011, 306 \\
\hline & PA12911 Laminar bead. & 92,4 & 7,57 & & & & 0,04 & 0,01 & Rovira et al. 2011, 306 \\
\hline & PA12864 Laminar bead. & 92,9 & 7,04 & & & & & 0,02 & Rovira et al. 2011, 306 \\
\hline
\end{tabular}




\begin{tabular}{|c|c|c|c|c|c|c|c|c|}
\hline & PA12863 Laminar bead. & 93,1 & 6,89 & & & & 0,02 & Rovira et al. 2011, 306 \\
\hline & PA12859 Laminar bead. & 92,3 & 7,70 & & & & 0,01 & Rovira et al. 2011, 306 \\
\hline & PA12903 Laminar bead. & 92,7 & 7,24 & & & 0,02 & 0,01 & Rovira et al. 2011, 306 \\
\hline & PA12907 Laminar bead. & 92,6 & 7,38 & & & 0,05 & 0,01 & Rovira et al. 2011, 306 \\
\hline & PA12910 Laminar bead. & 93,0 & 6,96 & & & 0,02 & 0,01 & Rovira et al. 2011, 306 \\
\hline & PA12913 Laminar bead. & 93,1 & 6,83 & & & & 0,03 & Rovira et al. 2011, 306 \\
\hline & PA12912 Laminar bead. & 92,6 & 6,95 & & & 0,07 & 0,02 & Rovira et al. 2011, 306 \\
\hline & PA12904 Laminar bead. & 93,4 & 6,54 & & & 0,02 & 0,02 & Rovira et al. 2011, 306 \\
\hline & PA20229 Laminar bead. & 94,8 & 5,1 & & & & & Rovira et al. 2011, 306 \\
\hline Loma del Belmonte 1, Almería & AA0992 Sheet & 94,71 & 5,25 & \multirow[b]{2}{*}{$<0.1$} & $\operatorname{Tr}$ & $\operatorname{Tr}$ & $\operatorname{Tr}$ & Rovira et al. 1997, 74 \\
\hline \multirow{14}{*}{ Perdigões, Portugal } & 10511 Sheet Frag. & 94.4 & 5.5 & & & & & Monge Soares et al. 2014, 122 \\
\hline & 11041 Sheet Frag. & 96.0 & 3.8 & $<0.1$ & & & & Monge Soares et al. 2014, 122 \\
\hline & 11866 Sheet Frag. & 98.9 & 1.0 & $<0.1$ & & & & Monge Soares et al. 2014,122 \\
\hline & 11867 Sheet Frag. & 99.1 & 0.8 & $<0.1$ & & & & Monge Soares et al. 2014, 122 \\
\hline & 11458 Sheet Frag. & 96.9 & 2.9 & $<0.1$ & & & & Monge Soares et al. 2014, 122 \\
\hline & 11452 Sheet Frag. & 98.9 & 0.9 & $<0.1$ & & & & Monge Soares et al. 2014,122 \\
\hline & 11460 Sheet Frag. & 99.1 & 0.7 & $<0.1$ & & & & Monge Soares et al. 2014, 122 \\
\hline & 11453 Sheet Frag. & 99.1 & 0.7 & $<0.1$ & & & & Monge Soares et al. 2014, 122 \\
\hline & 11455 Sheet Frag. & 96.4 & 3.2 & $<0.1$ & & & & Monge Soares et al. 2014, 122 \\
\hline & 11451 Sheet Frag. & 99.0 & 0.8 & $<0.1$ & & & & Monge Soares et al. 2014,122 \\
\hline & 11465 Sheet Frag. & 96.6 & 3.2 & $\begin{array}{l}<0.1 \\
\end{array}$ & & & & Monge Soares et al. 2014, 122 \\
\hline & 11459 Sheet Frag. & 96.7 & 3.1 & \multirow{2}{*}{$<0.1$} & & & & Monge Soares et al. 2014, 122 \\
\hline & 11454 Sheet Frag. & 99.3 & 0.6 & & & & & Monge Soares et al. 2014, 122 \\
\hline & 11450 Sheet Frag. & 96.8 & 3.0 & $<0.1$ & & & & Monge Soares et al. 2014, 122 \\
\hline \multicolumn{9}{|c|}{ Analytical Technique: SEM-EDX. Results \% wt } \\
\hline Site & Sample & $\mathrm{Au}$ & \multicolumn{2}{|l|}{ Ag } & $\mathrm{Cu}$ & \multicolumn{3}{|r|}{ Referencia } \\
\hline Loma de Belmonte 1, Almería & AULOM 02 Laminar bead (6) & 97,1 & \multicolumn{2}{|l|}{2,42} & 0,91 & \multicolumn{3}{|c|}{ Perea Caveda et al. 2010, $43 \mathrm{ff}$} \\
\hline \multirow{2}{*}{$\begin{array}{l}\text { Dolmen de Matarrubilla, Valencina de la Concepción, } \\
\text { Sevilla }\end{array}$} & AUMAT 01 Sheet (5) & 98,22 & \multicolumn{2}{|l|}{1,78} & $\mathrm{Nd}$ & \multicolumn{3}{|c|}{ Perea Caveda et al. 2010, $51 \mathrm{ff}$} \\
\hline & AUMAT 02 Decorated sheet (6) & 98,6 & \multicolumn{2}{|l|}{1,4} & $\mathrm{Nd}$ & & Perec & aveda et al. 2010, $51 \mathrm{ff}$ \\
\hline & AUPAS 01 Sheet (3) & 95,5 & 3,6 & & $\mathrm{Nd}$ & & Perec & aveda et al. 2010, $57 \mathrm{ff}$ \\
\hline Dolmen de La Pastora, Valencina d ela Concepción, & AUPAS 02 Sheet (4) & 95,7 & 2,7 & & $\mathrm{Nd}$ & & Perec & veda et al. $2010,57 \mathrm{ff}$ \\
\hline & AUPAS 03 Sheet (3) & 93,2 & 2,9 & & $\mathrm{Nd}$ & & Pere & avedaet al. 2010, $57 \mathrm{ff}$ \\
\hline Cau del Tossal Gros, Girona & TOS012 Bead (5) & 98,4 & 1,62 & & $\mathrm{Nd}$ & & Sori & Llopiset al. 2012, 153 \\
\hline & Analytical Te & ue: PIX & lits \% wt & & & & & \\
\hline Site & Sample & $\mathrm{Au}$ & $\mathrm{Ag}$ & & $\mathrm{Cu}$ & & & Reference \\
\hline El Carambolo, Camas, Sevilla & Decorated sheet & $95 \pm 3$ & $2,46 \pm 0,1$ & & $2,22 \pm 0,07$ & & Hun & rtiz et al. 2010 , table 1 \\
\hline & 10511 Sheet Frag. & 94.2 & 4.9 & & 0.06 & & Mon & Soares et al. 2014, 122 \\
\hline & 11041 Sheet Frag. & 96.0 & 2.4 & & 0.06 & & Mon & Soares et al. 2014, 122 \\
\hline Perdigões, Portugal & 11866 Sheet Frag. & 99.2 & 0.6 & & 0.03 & & Mon & Soares et al. 2014, 122 \\
\hline & 11867 Sheet Frag. & 99.1 & 0.7 & & 0.06 & & Mon & Soares et al. 2014, 122 \\
\hline & 11458 Sheet Frag. & 97.2 & 2.2 & & 0.05 & & Mon & Soares et al. 2014, 122 \\
\hline
\end{tabular}




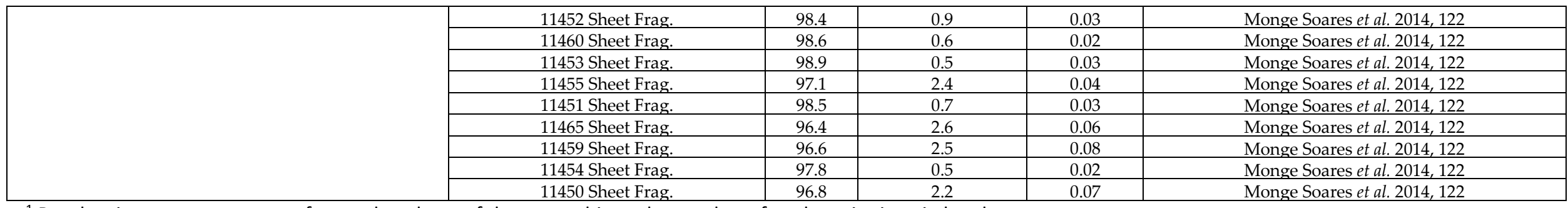

${ }^{1}$ Results given are an average of several analyses of the same object; the number of analyses is given in brackets.

* = Only quantified in one spot analysis.

** = Only quantified in two spots analyses. Average is reported.

${ }^{1}$ Hartmann 1982 states that theses beads come from cave 1. The Catalogue of the National Museum of Archaeology and Etnology in Lisboa, where they are deposited, reports that these beads come from grave 4 as well as Perea Caveda $(1991,28)$. 
Table 2. Neolithic and Chalcolithic golden finds from Iberia.

\begin{tabular}{|c|c|c|c|c|c|c|c|c|}
\hline Site & Province & Context & Morphology & $\begin{array}{c}\text { Lenght } \\
(\mathrm{mm})\end{array}$ & $\begin{array}{l}\text { Width } \\
(\mathrm{mm})\end{array}$ & Decoration & Perforations & Reference \\
\hline \multirow{3}{*}{ Alcalar } & \multirow{3}{*}{ Faro } & Tholos 4 & $\begin{array}{l}1 \text { Frag. } \\
\text { Sheet }\end{array}$ & 16 & 10 & Dotted decoration & 1 possible & $\begin{array}{c}\text { Leisner \& Leisner 1943, 239- } \\
\text { 40; Perea Caveda 1991, } 28\end{array}$ \\
\hline & & Tholos 4 & $\begin{array}{l}1 \text { Frag. } \\
\text { Sheet }\end{array}$ & & & Undecorated sheet with perforations & Yes & $\begin{array}{c}\text { Leisner \& Leisner 1943, } 239- \\
\text { 240; Perea Caveda } 1991 \\
\text {, } 28 .\end{array}$ \\
\hline & & Tholos 11 & $\begin{array}{l}1 \text { Frag. } \\
\text { Sheet }\end{array}$ & 45 & 24 & Two strips decorated with with triangles and lines. & 2 possible & $\begin{array}{c}\text { Leisner \& Leisner 1959, 262; } \\
\text { Perea Caveda 1991, } 28\end{array}$ \\
\hline Anta Grande de Zambujeiro & Évora & $\begin{array}{l}\text { Megalithic } \\
\text { structure }\end{array}$ & $\begin{array}{l}2 \text { Frags. } \\
\text { Sheet }\end{array}$ & & & Lineal motifs & $\mathrm{Si}$ & $\begin{array}{l}\text { Leisner \& Leisner 1943; } \\
\text { Hurtado Pérez 2009, } 151\end{array}$ \\
\hline Buraco da Pala & Mirandela & Natural Cave & Beads & $2.2-7$ & & 6 beads and one sheet & No & Comendador 1997, $193 \mathrm{ff}$ \\
\hline \multirow{4}{*}{ Cabezo Juré } & \multirow{4}{*}{ Huelva } & \multirow{4}{*}{ Settlement } & Sheet & 25.63 & 16.68 & Undecorated sheet & 1 possible & Nocete Calvoet al. 2014 \\
\hline & & & Sheet & 13 & 5.2 & Sheet & No & Nocete Calvoet al. 2014 \\
\hline & & & Sheet & 21 & 17.42 & Sheet & No & Nocete Calvoet al. 2014 \\
\hline & & & Sheet & 107.03 & 8.08 & Undecorated Sheet with one posible perforation & 1 possible & Nocete Calvoet al. 2014 \\
\hline Camino de las Yeseras & Madrid & Individual grave & $\begin{array}{c}\text { Beads and } \\
\text { foils }\end{array}$ & & & 22 laminar beads and 3 undecorated sheets & Yes & Blasco \& Ríos, 2010 \\
\hline $\begin{array}{c}\text { Cañada del Carrascal, Mairena } \\
\text { del Alcor }\end{array}$ & Sevilla & Colective burial & Sheet & & & Sheet fragment & Yes & $\begin{array}{c}\text { Leisner \& Leisner 1943, } 213- \\
\text { 214; Perea Caveda 1991, } 29\end{array}$ \\
\hline Cañada Honda de Gandul & Sevilla & Volective burial & Beads & & & 2 laminar beads & & $\begin{array}{c}\text { Leisner \& Leisner 1943, 206- } \\
\text { 208; Perea Caveda 1991, } 29\end{array}$ \\
\hline Cau del Tossal Gross & Girona & Natural Cave & Bead & 61.6 & 12.3 & Bead & & Soriano Llopis et al. 2012 \\
\hline Cerro de la Virgen, Orce & Granada & Settlement & $\begin{array}{c}3 \text { frags. } \\
\text { Sheet }\end{array}$ & & & Fragments of a perforated sheet & Yes & $\begin{array}{c}\text { Schüle 1980, cf. Perea Caveda } \\
1991,30 \\
\end{array}$ \\
\hline Collado de Mallo & Logroño & $\begin{array}{l}\text { Megalithic } \\
\text { structure }\end{array}$ & Bead & & & Laminar bead & & López \& Tudanca 1996 \\
\hline Collado Palomero I & Logroño & $\begin{array}{l}\text { Megalithic } \\
\text { structure }\end{array}$ & Beads & & & Laminar beads. One of them with linear decoration. & & Pérez Arrondo 1983, 56 \\
\hline Cova da Moura & Lisboa & Colective burial & Sheet & & & Undecorated sheet. & Yes & $\begin{array}{l}\text { Belo et al. 1961; Perea, 1991: } \\
28 .\end{array}$ \\
\hline
\end{tabular}




\begin{tabular}{|c|c|c|c|c|c|c|c|c|}
\hline Cova de la Pedrera & Alicante & Artificial Cave & Ring & & & Gold thread & & $\begin{array}{l}\text { Aparicio et al. 1981, 93; Perea, } \\
\text { 1991: } 30 .\end{array}$ \\
\hline Cueva de los Murciélagos & Granada & Natural Cave & Diadem & 530 & -- & Undecorated laminar diadem. & Yes & Góngora y Martínez, 1991 \\
\hline El Carambolo & Sevilla & Superficial find & Sheet & & & Decorated with triangular motifs. & & Hunt Ortiz et al. 2010 \\
\hline Ermegeira & Lisboa & Artificial cave & Bead & & & 9 laminar beads & & $\begin{array}{c}\text { Heleno 1942, 449-459; Perea } \\
\text { 1991: } 29 .\end{array}$ \\
\hline La Pijotilla & Badajoz & & Sheet & & & Decorated strips with zigzag motifs. & & $\begin{array}{l}\text { Hurtado Pérez \& Hunt Ortiz, } \\
1999\end{array}$ \\
\hline Las Canteras & Seville & $\begin{array}{l}\text { Megalithic } \\
\text { structure }\end{array}$ & $\begin{array}{c}\text { Decorated } \\
\text { Sheet }\end{array}$ & 46 & & Eye motif and lineal decoration. & Yes & $\begin{array}{l}\text { Hurtado Pérez \& Amores } \\
\text { Carredano, } 1984\end{array}$ \\
\hline \multirow{3}{*}{ Loma de Belmonte 1} & Almería & Tholos & Bead & & & Laminar beads & & Leisner \& Leisner 1943: 59. \\
\hline & Almería & Tholos & Sheet & & & Undecorated sheet. & & Leisner \& Leisner 1943, 59. \\
\hline & Almería & Tholos & Bead & & & Laminar bead & & Leisner\& Leisner 1943, 59. \\
\hline Los Algarbes & Cádiz & Artificial Cave & Sheet & 70 & 55 & $\begin{array}{c}\text { Spherical sheet decorated with geometric, chequered and } \\
\text { zidzag motifs. }\end{array}$ & & $\begin{array}{l}\text { Posac Mon, 1975; Perea, 1991: } \\
29 \\
\end{array}$ \\
\hline \multirow{2}{*}{ Marroquíes Bajos } & Jaén & $?$ & Sheet & $?$ & $?$ & Zigzag motifs. & Yes & Costa Caramé, 2009: 192 \\
\hline & Jaén & $?$ & Sheet & & & Undecorated sheet surronding a bone idol. & Yes & Costa Caramé, 2009: 192 \\
\hline Monte da Pena (Barro) & Lisboa & Tholos & Spiral & & & Spiral gold thread. & & Leisner 1965, 5 \\
\hline \multirow[b]{2}{*}{ Penha Verde } & Lisboa & Circular hut N.2 & Pin & & & Pin of circular section. & & Perea, 1991: 28. \\
\hline & Lisboa & Circular hut N.2 & Bead & & & Bead & & Perea, 1991: 28. \\
\hline Perdigões & Evora & Chamber of tomb 2 & Sheets & & & 14 Frag. sheets & One of them & Monge Soares et al. 2014 \\
\hline \multirow{3}{*}{ Quinta do Anjo } & Setúbal & Artificial cave 1 & Spiral & & & Spiral gold beld & & $\begin{array}{l}\text { Leisner, 1965: 120ff; Perea, } \\
\text { 1991: } 28 .\end{array}$ \\
\hline & Setúbal & Artificial cave 4 & Bead & & & Laminar bead & & $\begin{array}{l}\text { Leisner 1965, 129-131; Perea, } \\
\text { 1991: } 28 . \\
\end{array}$ \\
\hline & Setúbal & Artificial Cave 3 & Sheet & & & 1 undecorated sheet and 1 perforated sheet & Yes & Perea, 1991: 29 \\
\hline Senhora de Luz & Santarém & $\begin{array}{l}\text { Colective burial. } \\
\text { Artificial cave }\end{array}$ & Spiral & & & Spiral gold thread. & & Perea, 1991: 29. \\
\hline Sakulo & Navarra & $\begin{array}{l}\text { Megalithic } \\
\text { structure }\end{array}$ & Bead & 10 & 5 & Laminar bead & & Alday, 1992, 45 \\
\hline
\end{tabular}




\begin{tabular}{|c|c|c|c|c|c|c|c|c|}
\hline São Pedro do Estoril & Lisboa & Artificial Cave & 4 Spirals & & & 4 Spiral gold belds & & $\begin{array}{l}\text { Leisner et al. 1964; Leisner } \\
\text { 1965: 109; Perea 1991: } 27 .\end{array}$ \\
\hline Trikuaizti I & Gipuzkoa & $\begin{array}{l}\text { Megalithic } \\
\text { structure }\end{array}$ & Beads & & & 2 laminar beads & & Alday 1992,44 \\
\hline Veiga dos Mouros & A Coruña & Tholos 240 & Diadem & 345 & 32 & Undecorated laminar diadem with perforations & Yes & Comendador 1997, 64 \\
\hline Valdehiguero & Logroño & Natural Cave & Sheet & 50 & 30 & Circular shape sheet with a stem & No & Luezas \& Rovira 2004 \\
\hline Zambujal & Lisboa & $\begin{array}{l}\text { Dwelling V with } \\
\text { evidences of } \\
\text { copper production }\end{array}$ & Bead & & & bead & & Sangmeister \& Schubart 1981. \\
\hline
\end{tabular}

Table 3. Copper Age gold artefacts found at Valencina de la Concepción (NA: Not Available; NP: Not Published)

\begin{tabular}{|c|c|c|c|c|c|c|c|c|}
\hline Context & $\begin{array}{l}\text { Context } \\
\text { Type }\end{array}$ & Description & $\begin{array}{l}\text { Length } \\
\text { (cm) }\end{array}$ & $\begin{array}{l}\text { Width } \\
\text { (cm) }\end{array}$ & $\begin{array}{l}\text { Weight } \\
\text { (g) }\end{array}$ & Decoration & $\begin{array}{c}\text { Lateral } \\
\text { perforations }\end{array}$ & Reference \\
\hline La Pastora & $\begin{array}{l}\text { Megalithic } \\
\text { structure }\end{array}$ & $\begin{array}{c}\text { Three undecorated } \\
\text { narrow sheets }\end{array}$ & & & & Undecorated & No & $\begin{array}{l}\text { Perea Caveda 1991, 30; Perea Caveda } \\
\text { et al. 2010, 56-61 }\end{array}$ \\
\hline Matarrubilla & $\begin{array}{l}\text { Megalithic } \\
\text { structure }\end{array}$ & $\begin{array}{l}\text { Circa thirteen decorated } \\
\text { and undecorated sheet } \\
\text { fragments }\end{array}$ & -- & -- & -- & Linear and chess-board motifs & No & $\begin{array}{l}\text { Collantes de Terán 1969; Perea Caveda } \\
\text { et al. 2010, 51-55 }\end{array}$ \\
\hline $\begin{array}{l}\text { Señorío de Guzmán, Tomb } \\
1\end{array}$ & $\begin{array}{l}\text { Megalithic } \\
\text { structure }\end{array}$ & $\begin{array}{l}\text { One decorated sheet } \\
\text { fragment }\end{array}$ & $\mathrm{NP}$ & $\mathrm{NP}$ & NP & Linear and dotted & $\mathrm{NP}$ & $\begin{array}{l}\text { Arteaga Matute \& Cruz-Auñón } \\
\text { Briones 2001, 647; López Aldana et al. } \\
\text { in press }\end{array}$ \\
\hline $\begin{array}{l}\text { Señorío de Guzmán, Tomb } \\
2\end{array}$ & $\begin{array}{l}\text { Megalithic } \\
\text { structure }\end{array}$ & One sheet & $\mathrm{NP}$ & $\mathrm{NP}$ & $\mathrm{NP}$ & $\mathrm{NP}$ & NP & López Aldana et al.in press \\
\hline $\begin{array}{l}\text { Señorío de Guzmán, Tomb } \\
5\end{array}$ & $\begin{array}{l}\text { Megalithic } \\
\text { structure }\end{array}$ & Three beads & $\mathrm{NP}$ & $\mathrm{NP}$ & $\mathrm{NP}$ & $\mathrm{NP}$ & NP & López Aldana et al. in press \\
\hline Montelirio & $\begin{array}{l}\text { Megalithic } \\
\text { structure }\end{array}$ & $\begin{array}{c}\text { Four sheets, one of them } \\
\text { decorated }\end{array}$ & $\mathrm{NP}$ & NP & NP & NP & NP & NP \\
\hline $\begin{array}{l}\text { PP4-Montelirio, Structure } \\
10.029\end{array}$ & $\begin{array}{c}\text { Negative } \\
\text { Feature (Pit) }\end{array}$ & One decorated sheet & 20,5 & 9,8 & c. 20 & Linear, zigzag, dotted and eye motifs & Yes & this paper \\
\hline $\begin{array}{l}\text { Trabajadores Street, } \\
\text { Structure-Stratigraphic Unit } \\
56\end{array}$ & $\begin{array}{l}\text { Negative } \\
\text { Feature (Pit) }\end{array}$ & One undecorated sheet & 16 & 1 & 3.24 & Undecorated & No & $\begin{array}{l}\text { López Aldana \& Pajuelo Pando 2013, } \\
163\end{array}$ \\
\hline Las Veinte & $\begin{array}{c}\begin{array}{c}\text { Unknown } \\
\text { (possibly }\end{array} \\
\text { Megalithic } \\
\text { structure) }\end{array}$ & $\begin{array}{l}\text { Some fragments of gold } \\
\text { sheets }\end{array}$ & NP & NP & NP & NA & NA & $\begin{array}{l}\text { Fernández Gómez and Oliva Alonso } \\
1983,45\end{array}$ \\
\hline
\end{tabular}




\begin{tabular}{|c|c|c|c|c|c|c|c|c|}
\hline Caño Ronco & $\begin{array}{c}\text { Megalithic } \\
\text { structure }\end{array}$ & One thin gold blade & NA & NA & NA & Undecorated & NA & $\begin{array}{l}\text { Cabrero García, 1985; López Aldana et } \\
\text { al. in press }\end{array}$ \\
\hline Alamillo Street & 'Hut floor' & Nugget & 0.67 & NP & 1.95 & -- & -- & López Aldana et al. 2001 \\
\hline
\end{tabular}

